\title{
Drug therapy for hereditary cancers
}

\author{
Evgeny N Imyanitov ${ }^{1,2,3^{*}}$ and Vladimir M Moiseyenko ${ }^{2}$
}

\begin{abstract}
Tumors arising in patients with hereditary cancer syndromes may have distinct drug sensitivity as compared to their sporadic counterparts. Breast and ovarian neoplasms from BRCA1 or BRCA2 mutation carriers are characterized by deficient homologous recombination (HR) of DNA, that makes them particularly sensitive to platinum compounds or inhibitors of poly (ADP-ribose) polymerase (PARP). Outstandingly durable complete responses to high dose chemotherapy have been observed in several cases of BRCA-related metastatic breast cancer (BC). Multiple lines of evidence indicate that women with BRCA1-related BC may derive less benefit from taxane-based treatment than other categories of $\mathrm{BC}$ patients. There is virtually no reports directly assessing drug response in hereditary colorectal cancer (CRC) patients; studies involving non-selected (i.e., both sporadic and hereditary) CRC with high-level microsatellite instability (MSI-H) suggest therapeutic advantage of irinotecan. Celecoxib has been approved for the treatment of familial adenomatous polyposis (FAP). Hereditary medullary thyroid cancers (MTC) have been shown to be highly responsive to a multitargeted tyrosine kinase inhibitor vandetanib, which exerts specific activity towards mutated RET receptor. Given the rapidly improving accessibility of DNA analysis, it is foreseen that the potential predictive value of cancer-associated germ-line mutations will be increasingly considered in the future studies.
\end{abstract}

\section{Introduction}

Search for hereditary cancer genes was always regarded as a high priority translational research with immediate health impact. It was foreseen, that the discovery of tumor predisposing mutations and the development of appropriate genetic tests will allow identifying yet healthy subjects, who are at nearly fatal risk of specific type of cancer and thus may benefit from a timely medical intervention. Since the discovery of major cancer genes in the mid 1990s, thousands of mutation carriers have been subjected to intensive surveillance programs in order to secure early diagnosis of the disease [1]. The preventive surgery has been applied in some instances, that led to a proven reduction of cancer-specific mortality [2]. While the initial practical focus of cancer genetic research was limited to various aspects of cancer detection and prevention, it is now getting increasingly recognized that hereditary tumors may have distinct bioclinical characteristics and thus require tailored treatment strategies.

\footnotetext{
* Correspondence: evgeny@imyanitov.spb.ru

'Laboratory of Molecular Oncology, N.N. Petrov Institute of Oncology, St.Petersburg, 197758, Russia

Full list of author information is available at the end of the article
}

\section{Breast-ovarian cancer syndrome}

The best-known hereditary cancer genes, BRCA1 and $B R C A 2$, contribute to substantial share of breast and ovarian tumor incidence around the globe, and have been studied with significant level of comprehension [3]. Mutations in other relevant genes, such as CHEK2, PALB2 (FANCN), ATM, NBN (NBS1), BRIP1 (FANCJ, $B A C H 1), B L M$, are less frequent and have not been subjected yet to systematic clinical studies.

\section{$B R C A 1$ and $B R C A 2$}

$B R C A 1$ and $B R C A 2$ genes play a central role in the repair of double-strand DNA breaks by homologous recombination (HR). Cancers in BRCA heterozygous individuals arise due to somatic inactivation of the remaining wild-type allele of the gene. This provides a critical biological difference between cancerous and normal cells: while BRCA-driven tumors are characterized by HR deficiency, normal tissues from the same individuals retain non-affected $B R C A$ allele and the ability to cope with DNA damage [4,5]. Although BRCA1- and $B R C A 2$-related cancers demonstrate somewhat distinct picture of genetic abnormalities [6,7], they both have increased number of gross chromosomal aberrations and therefore higher tumor grade [8-11]. Cells carrying multiple genetic lesions due to HR defect are normally
C Biomed Central

() 2011 Imyanitov and Moiseyenko; licensee BioMed Central Ltd. This is an Open Access article distributed under the terms of the Creative Commons Attribution License (http://creativecommons.org/licenses/by/2.0), which permits unrestricted use, distribution, and reproduction in any medium, provided the original work is properly cited. 
eliminated by p53-guided defense mechanisms; there are convincing evidence from both human studies and murine models that $p 53$ inactivation is an absolute prerequisite for the propagation of $B R C A$-dysfunctional tumors cells [12-15].

$B R C A 1$ has a wider spectrum of functions than $B R C A 2[16,17]$. In addition to DNA repair, $B R C A 1$ is involved in breast cell differentiation and transcriptional regulation of the estrogen receptor (ER) [18]. It has been repeatedly shown, that the majority of $B R C A 1$ mutated breast carcinomas (BC) do not express ER, while the hormonal receptor pattern in BRCA2-associated $\mathrm{BC}$ is similar to sporadic cases [19]. BRCA1 is also essential for the mitotic spindle checkpoint as it triggers cellular suicide in response to microtubule damage [20].

\section{Preclinical studies}

A large number of preclinical studies aimed to assess specific sensitivity of BRCA1- and BRCA2-defective cells to various anticancer agents. Surprisingly, while the effect of individual compounds has been repeatedly evaluated in diverse model systems (Table 1), there was virtually no attempt to compare clinically relevant combinations of the drugs (Table 2). This may constitute a critical gap between preclinical and clinical research, as single-agent therapy is almost never used as initial treatment of breast or ovarian cancers. It is highly likely, that the standard combinations of cytotoxic compounds produce distinct spectrum of DNA lesions and therefore mediate distinct responses of $B R C A$-deficient cells when compared to the same drugs acting alone.

There is an excellent consistency in the literature regarding high sensitivity of both $B R C A 1$ - and $B R C A 2$ deficient cells to cisplatin and other platinum derivatives [21-40]. It is believed that the DNA crosslinks caused by platinating agents ultimately require homologous recombination to correctly repair DNA damage, so the BRCAinactive cells cannot cope with this class of drugs. Similar consistency has been observed for another DNAcrosslinking agent, mitomycin C [28,33,36,41-44].

Controversial data have been obtained for doxorubicin, a widely used anthracycline antibiotic with multiple mechanisms of action. Doxorubicin causes double-strand breaks in the target DNA, so it may be particularly effective for the cells lacking error-free repair of this type of lesion. Some investigations demonstrated high sensitivity of BRCA-deficient cells to doxorubicin [24,45,46], while other reports described entirely opposite findings [26, 33, 34. 36]. Another topoisomerase II inhibitor, etoposide, showed selective efficacy against $B R C A$-defective cell in all but one studies [23-25,36,47,48].

Analysis of microtubule poisons produced even more complicated picture. It has been repeatedly demonstrated that BRCA1-deficient cells are significantly less sensitive to taxanes or vinca alkaloids than cells with preserved BRCA1 function [23,25,26,49-51]. Although these observations are in good agreement with the established role of BRCA1 in cellular response to microtubule damage [20], one cannot ignore the existence of sound contradictory data. Zhou et al. [52] reported increased sensitivity of BRCA1-mutated ovarian cancer (OC) cell line to paclitaxel as compared to isogenic cells with reconstituted $B R C A 1$ function. Tassone et al. [53] showed high sensitivity of BRCA1-deficient breast cancer cells to vinorelbine and argued that the differences in the mechanism of action between various microtubule interfering drugs have to be considered while interpreting the results of $B R C A 1$ studies. DeLigio and Zorio [20] commented that the tissue origin of the BRCA1mutated cells may be essential in determining the response to taxanes and vinca alkaloids. BRCA2 preclinical studies suggested little impact of the status this gene in determining the response to microtubule interfering agents [27,33,46,47].

Alkylating agents are almost always included in the standard schemes for the treatment of breast and ovarian cancers. Surprisingly, this class of drugs has not been subjected to systematic studies in BRCA-deficient model systems. Single-agent cyclophosphamide showed only slight antitumor activity against BRCA1-mutated human breast cancer xenografts growing in nude mice [31]. At the same time, high-throughput pharmaceutical screen involving BRCA2-deficent vs. BRCA2-proficient mouse mammary tumor cell lines identified alkylating agents (chlorambucil, melphalane, nimustine) as the most potent and specific inhibitors of cell growth; furthermore, high efficacy of these drugs was confirmed in animal experiments [38].

Topoisomerase I inhibitors are rarely used for the treatment of breast cancer, but included in some therapeutic schemes for ovarian cancer. High sensitivity to these drugs was suggested for both BRCA1- [24,54] and $B R C A 2$-defective cells $[38,46,55]$, although controversial results have been reported as well [27].

There is a good agreement in the literature that single-agent antimetabolites, 5-fluorouracil and gemcitabine, do not exert specific action against BRCA-deficient tumors $[24,33,46]$. In contrast, 6 -thioguanine was identified by a chemical library screen as the most potent antagonist of BRCA2-mutated cells [46].

There is a growing number of studies demonstrating pronounced efficacy of specific inhibitors of poly (ADPribose) polymerase (PARP) against $B R C A$-deficient cancers $[31,33,38-40,56-60]$. It is suggested that inactivation of PARP interferes with the repair of spontaneous DNA single-strand breaks. In the normal cells these lesions are converted to double-strand breaks during DNA replication and then eliminated by homologous 
Table 1 Drug sensitivity of breast-ovarian cancer syndrome related tumors: preclinical evidence

\begin{tabular}{|c|c|}
\hline \multirow[t]{2}{*}{ Study } & Study design and main findings \\
\hline & $B R C A 1$ \\
\hline Husain et al. [21] & $\begin{array}{l}\text { Antisense inhibition of BRCA1 expression in the cisplatin-resistant clone of SKOV3 ovarian cancer cell line restore } \\
\text { sensitivity to the drug. }\end{array}$ \\
\hline Bhattacharyya et al. [22] & $\begin{array}{l}\text { BRCA1-deficient mouse embryonic stem cells were more sensitive to cisplatin than isogenic BRCA1-proficient cell } \\
\text { as determined by a clonogenic assay. }\end{array}$ \\
\hline Brodie et al. [45] & $\begin{array}{l}\text { Cell lines, which were generated from mammary tumors growing in genetically engineered BRCA1-deficient mice } \\
\text { demonstrated high sensitivity to doxorubicin in a cell survival assay. }\end{array}$ \\
\hline Lafarge et al. [23] & $\begin{array}{l}\text { Inhibition of BRCA1 expression in HBL100 breast cancer cells led to increased sensitivity to cisplatin and } \\
\text { etoposide, but resistance to paclitaxel and vincristine, as assessed by the rhodamine B proliferation test. }\end{array}$ \\
\hline Moynahan et al. [42] & $\begin{array}{l}\text { Increased sensitivity of BRCA1-deficient mouse embryonic stem cells to mitomycin C in a clonogenic assay; } \\
\text { reversed upon correction of BRCA1-mutated allele by gene targeting. }\end{array}$ \\
\hline Mullan et al. [49] & $\begin{array}{c}\text { Tetracycline regulated inducible expression of } B R C A 1 \text { in MBR62-bcl2 breast cancer cell line increased sensitivity to } \\
\text { paclitaxel and vincristine, by did not affect the response to cisplatin, doxorubicin, cyclophosphamide, 5- } \\
\text { fluorouracil, or bleomycin, as determined by a clonogenic assay. }\end{array}$ \\
\hline Fedier et al. [24] & $\begin{array}{l}\text { Increased sensitivity of BRCA1-deficient mouse embryonic cells to the antiproliferative effect of camptothecin, } \\
\text { topotecan, doxorubicin, mitoxantrone, etoposide, carboplatin, oxaliplatin, but not of } 5 \text {-fluoroucil, gemcitabine, } \\
\text { paclitaxel, docetaxel; increased apoptosis in response to doxorubicin but not to docetaxel. }\end{array}$ \\
\hline Quinn et al. [25] & $\begin{array}{c}\text { BRCA1-deficiency is associated in increased sensitivity to apoptosis caused by etoposide, bleomycin or cisplatin, } \\
\text { but resistance to apoptotic response to paclitaxel or vinorelbine. }\end{array}$ \\
\hline Tassone et al. [26] & $\begin{array}{l}\text { BRCA1-mutant HCC1937 breast cancer cells were more sensitive to cisplatin, but less sensitive to doxorubicin an } \\
\text { paclitaxel, than BRCA1-proficient MCF7 and MDA-MB-231 cells, as determined by the MTT test. Transfection of th } \\
\text { wild-type BRCA1 in HCC1937 cells decreased their sensitivity to cisplatin, but restored sensitivity to doxorubicin } \\
\text { and paclitaxel; this effect was at least in part attributed to the modulation of the apoptotic response. }\end{array}$ \\
\hline Zhou et al. [52] & $\begin{array}{c}\text { SNU251 ovarian cancer cell line carrying truncation of } 49 \text { C-terminal aminoacids of the BRCA1 gene (partial } \\
\text { deletion of } 2^{\text {nd }} \text { BRCT domain) demonstrated increased sensitivity to paclitaxel in a cell viability assay; this effect } \\
\text { was reversed by the introduction of the wild-type BRCA1. }\end{array}$ \\
\hline Farmer et al. [57] & $\begin{array}{c}\text { siRNA directed or chemical inhibition of PARP profoundly inhibited clonogenicity of BRCA1-deficient mouse } \\
\text { embryonic stem cells as compared to BRCA1-proficient isogenic cell lines; similar results were obtained upon } \\
\text { simultaneous inhibition of BRCA1 and PARP in MCF7 breast cancer cell line. This effect was attributed to the } \\
\text { massive growth arrest and subsequent apoptosis. }\end{array}$ \\
\hline
\end{tabular}

Tassone et al. [53] BRCA1-mutant HCC1937 breast cancer cells were more sensitive to vinorelbine than BRCA1-proficient MCF7 and MDA-MB-468 cells; when docetaxel was used, HCC1937 were similarly sensitive as compared to MCF7, and less sensitive than MDA-MB-468 (MTT test). Transfection of the wild-type BRCA1 in HCC1937 cells rendered resistance

to vinorelbine, but slightly increased sensitivity to docetaxel. The effect of vinorelbine was at least in part attributed to the modulation of the apoptotic response.

Yun et al. [44] BRCA1-deficient mouse embryonic fibroblasts were significantly more sensitive to mitomycin C than BRCA1-wildtype expressing isogenic cells, as demonstrated by a clonogenic assay. The effect of mitomycin $C$ is mediated through massive S-phase arrest followed by apoptosis.

\begin{tabular}{|c|c|}
\hline Bartz et al. [29] & BRCA1 inhibition strongly increased sensitivity of HeLa cells to cisplatin, as revealed by siRNA screen. \\
\hline Chabalier et al. [50] & $\begin{array}{l}\text { siRNA-directed inactivation of BRCA7 function in MCF7 breast cancer cells rendered resistance to paclitaxel- } \\
\text { induced growth inhibition and mitotic arrest. }\end{array}$ \\
\hline Xing and Orsulic [30] & $\begin{array}{c}\text { BRCA1-deficient transformed mouse ovarian surface epithelial cell lines demonstrated higher sensitivity to } \\
\text { cisplatin as compared to BRCA7-proficient isogenic cells, while no differential sensitivity to paclitaxel was } \\
\text { observed. }\end{array}$ \\
\hline Donawho et al. [31] & $\begin{array}{c}\text { Veliparib potentiated inhibitory effect of cisplatin, carboplatin and cyclophosphamide towards human BRCA1- } \\
\text { mutated breast cancer xenografts (MX-1) growing in immunocompromised mice. }\end{array}$ \\
\hline Rottenberg et al. [32] & $\begin{array}{l}\text { Doxorubicin, docetaxel and cisplatin inhibited growth of mammary tumors in genetically engineered BRCA1- } \\
\text { deficient mice. Treated tumors eventually acquired resistance to doxorubicin and docetaxel, but not to cisplatin. }\end{array}$ \\
\hline Treszezamsky et al. [48] & $\begin{array}{c}\text { BRCA1-mutant HCC1937 breast cancer cells showed increased sensitivity to etoposide as compared to BRCA1- } \\
\text { wild-type expressing isogenic cells, as shown by a clonogenic assay. }\end{array}$ \\
\hline Yamane et al. [117] & $\begin{array}{c}\text { BRCA1-mutant HCC1937 breast cancer cell line showed increased survival and decreased apoptosis in response 6- } \\
\text { thioguanine as compared to BRCA7-wild-type expressing isogenic cells. }\end{array}$ \\
\hline Shafee et al. [34] & $\begin{array}{c}\text { Cisplatin caused marked regression of BRCA1-deficient tumors growing in genetically engineered mice, while } \\
\text { doxorubicin exerted only marginal effect. }\end{array}$ \\
\hline Rottenberg et al. [59] & $\begin{array}{l}\text { Olaparib inhibited growth of mammary tumors in genetically engineered BRCA1-deficient mice. Combination of } \\
\text { olaparib with cisplatin or carboplatin produced longer recurrence-free and overall survival than olaparib alone. }\end{array}$ \\
\hline
\end{tabular}




\section{Table 1 Drug sensitivity of breast-ovarian cancer syndrome related tumors: preclinical evidence (Continued)}

\begin{tabular}{|c|c|}
\hline Promkan et al. [51] & $\begin{array}{c}\text { shRNA-directed inhibition of BRCA1 expression in MCF7 and MDA-MB-231 breast cancer cells decreased } \\
\text { cytotoxicity of paclitaxel. Breast cancer cell lines carrying BRCA1 mutation (HCC1937 and MDA-MB-436) also } \\
\text { demonstrated low sensitivity to paclitaxel. }\end{array}$ \\
\hline Santarosa et al. [36] & $\begin{array}{c}\text { Antisense inhibition of BRCA1 expression in HBL100, MCF7 and T47D breast cancer cells led to increased } \\
\text { sensitivity to mitomycin C and cisplatin, but not to doxorubicin and etoposide, as determined by a clonogenic } \\
\text { assay. Similar results were obtained on the BRCA1-mutated HCC1937 breast cancer cell line. This effect was } \\
\text { attributed to premature senescence of the chemosensitive cells. }\end{array}$ \\
\hline Tassone et al. [37] & $\begin{array}{c}\text { Cisplatin induced almost complete growth inhibition of HCC1937-derived (BRCA1-mutated) breast cancer } \\
\text { xenografts, while BRCA1-reconsituted HCC1937 xenografted tumors showed only partial response to cisplatin } \\
\text { treatment. }\end{array}$ \\
\hline Zander et al. [54] & Topotecan inhibited growth of mammary tumors in genetically engineered BRCA1-deficient mice. \\
\hline Drew et al. [39] & $\begin{array}{l}\text { AG014699 (PARP inhibitor) was highly cytotoxic against breast cancer cells with mutationally inactivated (MDA- } \\
\text { MB-436) or epigenetically silenced (UACC3199) BRCA1, as determined by a clonogenic assay. BRCA1-deficient } \\
\text { HCC1937 cells were more sensitive to AG014699 than the isogenic cell line with restored BRCA1 function } \\
\text { (rhodamine B proliferation test). AG014699 and carboplatin efficiently inhibited growth of MDA-MB-436 and } \\
\text { UACC3199 derived xenografted tumors. }\end{array}$ \\
\hline Goldberg et al. [60] & $\begin{array}{l}\text { Nanoparticle-mediated delivery of PARP1-specific siRNA inhibited growth of BRCA1-deficient mouse ovarian } \\
\text { cancer allografts; this effect was at least in part attributed to apoptotic death of targeted cells. }\end{array}$ \\
\hline \multicolumn{2}{|r|}{ BRCA2 } \\
\hline Abbott et al. [47] & $\begin{array}{l}\text { Increased sensitivity of BRCA2-deficient pancreatic cancer cell line CAPAN1 to mitoxantrone, etoposide and } \\
\text { amsacrine, but not to paclitaxel, as assessed by a cell survival assay. Antisense down-regulation of BRCA2 in } \\
\text { BRCA2-proficient pancreatic cancer cells resulted in hypersensitivity to mitoxantrone. CAPAN1 xenografted tumors } \\
\text { showed nearly complete response to mitoxantrone and marked response to etoposide. }\end{array}$ \\
\hline Yu et al. [41] & $\begin{array}{c}\text { Increased sensitivity of BRCA2-deficient vs. BRCA2-wild-type mouse lymphocytes to the mitomycin } C \text {, as } \\
\text { determined by a cell survival assay. }\end{array}$ \\
\hline Rahden-Staron et al, [55] & Increased sensitivity of BRCA2-deficient Chinese hamster VS8 fibroblasts to camptothecin in a cell survival assay. \\
\hline Samouelian et al. [27] & $\begin{array}{l}\text { Increased sensitivity of BRCA2-deficient ovarian cancer cell line TOV81 to cisplatin, but not to camptothecin or } \\
\text { paclitaxel, as assessed by a cell survival assay. }\end{array}$ \\
\hline van der Heijden et al. [28] & $\begin{array}{l}\text { Increased sensitivity of BRCA2-deficient pancreatic cancer cell line CAPAN1 to cisplatin and mitomycin C, as } \\
\text { shown by a cell survival assay. Increased sensitivity to mitomycin C induced G2/M cell cycle growth arrest. }\end{array}$ \\
\hline Bryant et al. [56] & $\begin{array}{l}\text { Chemical inhibition of PARP profoundly inhibited clonogenicity of BRCA2-deficient Chinese hamster VS8 } \\
\text { fibroblasts as compared to parental V79 cells. Similar results were obtained upon simultaneous inhibition of } \\
\text { BRCA2 and PARP in MCF7 and MDA-MB-231 breast cancer cell lines. }\end{array}$ \\
\hline Farmer et al. [57] & $\begin{array}{c}\text { siRNA directed or chemical inhibition of PARP profoundly inhibited clonogenicity of BRCA2-deficient mouse } \\
\text { embryonic stem cells as compared to BRCA2-proficient isogenic cell lines; similar results were obtained on BRCA2- } \\
\text { deficient Chinese hamster ovarian cancer cell line. This effect was attributed to the massive growth arrest and } \\
\text { subsequent apoptosis. Chemical PARP inhibitor suppressed growth of BRCA2-deficient xenografts in athymic } \\
\text { mice. }\end{array}$ \\
\hline $\begin{array}{l}\text { Gallmeier and Kern [155], } \\
\text { McCabe et al. [58] }\end{array}$ & $\begin{array}{l}\text { BRCA2-deficient CAPAN1 pancreatic cancer cells were sensitive to highly active PARP inhibitors, while moderately } \\
\text { active PARP inhibitors did not affect cell survival. }\end{array}$ \\
\hline van der Heijden et al. [43] & BRCA2-deficient CAPAN1 xenografted tumors showed marked response to mitomycin $\mathrm{C}$. \\
\hline Bartz et al. [29] & BRCA2 inhibition strongly increased sensitivity of HeLa cells to cisplatin, as revealed by siRNA screen. \\
\hline Treszezamsky et al. [48] & $\begin{array}{l}\text { BRCA2-deficient EUFA423 fibroblasts showed increased sensitivity to etoposide as compared to BRCA1-wild-type } \\
\text { expressing isogenic cells, as shown by a clonogenic assay. }\end{array}$ \\
\hline Evers et al. [33] & $\begin{array}{l}\text { Olaparib, cisplatin, mitomycin } C \text { and temozolomide effectively inhibited growth of BRCA2-deficent vs. BRCA2- } \\
\text { proficient mouse cell lines, while doxorubicin, docetaxel and 5-fluorouracil showed no difference. Synergism } \\
\text { between olaparib and cisplatin was observed for BRCA2-deficient but not for BRCA2-proficient cells. }\end{array}$ \\
\hline Hay et al. [35] & $\begin{array}{l}\text { BRCA2-deficient mammary tumors growing in genetically engineered mice demonstrated high sensitivity to } \\
\text { olaparib and carboplatin. }\end{array}$ \\
\hline Evers et al. [38] & $\begin{array}{c}\text { High-throughput pharmaceutical screen involving BRCA2-deficent vs. BRCA2-proficient mouse mammary tumor } \\
\text { cell lines identified alkylating agents (chlorambucil, melphalane, nimustine) as the most potent and specific } \\
\text { inhibitors of cell growth; differential inhibition was also registered for carboplatin, camptothecin and ellipticine. } \\
\text { BRCA2-deficient mammary tumors, either transplanted or growing in genetically engineered mice, demonstrated } \\
\text { high sensitivity to alkylating compounds. Synergistic interaction between alkylators and olaparib was observed } \\
\text { both in vitro and in vivo. }\end{array}$ \\
\hline Issaeva et al. [46] & $\begin{array}{c}\text { Chemical library screen identified 6-thioguanine as the most potent inhibitor of the survival of BRCA2-deficient } \\
\text { human sarcoma U2OS cells and Chinese hamster VS8 fibroblasts. High efficacy of both 6-thioguanine and } \\
\text { AG014699 (PARP inhibitor) against BRCA2-deficient xenografted tumors. Comparison of BRCA2-deficient VS8 cells } \\
\text { versus isogenic BRCA2-expressing VS8+B2 cells: higher sensitivity to temozolomide, camptothecin and } \\
\text { doxorubicin, but lower sensitivity to gemcitabine and paclitaxel. }\end{array}$ \\
\hline
\end{tabular}


Table 1 Drug sensitivity of breast-ovarian cancer syndrome related tumors: preclinical evidence (Continued)

\begin{tabular}{|c|c|}
\hline Drew et al. [39] & $\begin{array}{l}\text { AG014699 (PARP inhibitor) was highly cytotoxic against BRCA2-deficient CAPAN1 pancreatic cancer cells, as } \\
\text { determined by a clonogenic assay. AG014699 and carboplatin efficiently inhibited growth of CAPAN1-derived } \\
\text { tumor xenografts, with the most pronounced effect while using combination of these drugs. }\end{array}$ \\
\hline Kortmann et al. [40] & $\begin{array}{l}\text { BRCA2-deficient ovarian cancer xenografts showed marked response to olaparib, carboplatin, and olaparib plus } \\
\text { carboplatin, whereas BRCA2-proficient xenografts responded only to carboplatin and olaparib plus carboplatin. }\end{array}$ \\
\hline \multicolumn{2}{|r|}{ PALB2 } \\
\hline Villarroel et al. [97] & $\begin{array}{l}\text { High sensitivity of PALB2-deficient xenografted pancreatic tumor to mitomycin C and cisplatin but not to } \\
\text { gemcitabine. }\end{array}$ \\
\hline \multicolumn{2}{|r|}{ Other genes } \\
\hline McCabe et al. [93] & $\begin{array}{l}\text { RNA-interference driven inhibition of NBN (NBS1), CHEK2 or some other genes involved in homologous } \\
\text { recombination increased sensitivity of cultured cells to PARP inhibitors, as determined by cell survival assays. }\end{array}$ \\
\hline Bartz et al. [29] & BRIP1 inhibition strongly increased sensitivity of HeLa cells to cisplatin, as revealed by siRNA screen. \\
\hline
\end{tabular}

recombination. Since hereditary cancers are deficient for HR due to loss of both alleles of either BRCA1 or $B R C A 2$, they cannot eliminate double-strand breaks by error-free mechanism. As result, cancers arising in $B R C A$ carriers are selectively sensitive to PARP inhibitors, while the normal tissues from the same individuals retain a non-affected $B R C A$ allele and are therefore capable to compensate the consequences of decreased PARP activity [61,62]. PARP inhibitors appear to be the only class of drugs which was assessed in preclinical models in combination with other anticancer agents; synergism of PARP with platinum compounds and alkylating agents has been reported [31,33,38,39,59].

\section{Breast cancer}

The majority of $B R C A 2$ - and a certain fraction of $B R C A 1$-related $B C$ express estrogen and/or progesterone receptors and are therefore expected to benefit from endocrine therapy. While a couple of studies examined the chemopreventive impact of tamoxifen or oophorectomy in BRCA carriers [63] and some investigators analyzed benefits from the adjuvant use of estrogen antagonists [64], there is no reports assessing the role of $B R C A$ status in determining the effect of endocrine intervention in neoadjuvant or metastatic setting.

Data on the efficacy of conventional chemotherapeutic schemes in BRCA-related vs. sporadic breast cancers are summarized in the Table 2. Several research groups reported outcomes of anthracycline-based therapy. Delagoge et al. [65], Chappuis et al. [66], Warner et al. [67], Hubert et al. [68], Fourquet et al. [69] and Byrski et al. [70] provided evidence for remarkable sensitivity of $B R C A 1 / 2$-related cancers to the neoadjuvant anthracycline-containing regimens. Interestingly, Hubert et al. [68] and Wong Wong Keet et al. [71] observed worse outcomes in BRCA2 vs. BRCA1 carriers. The data of Petit et al. [72] are in strong disagreement with the above observations: in their study only $2 / 12$ (17\%) of $B R C A 1$ carriers receiving 5-fluorouracil, epirubicin and cyclophosphamide achieved pathologic complete response (pCR), while pCR was detected in 21/43 (49\%) sporadic triple-negative $\mathrm{BC}$.

The only available study of metastatic BC included patients treated by either anthracycline-based or CMF (CMF-like) therapy [73]. In contrast to neoadjuvant series of Hubert et al. [68] and Wong Wong Keet et al. [71], significantly improved outcomes were detected in $B R C A 2$ but not BRCA1 carriers. Low efficacy of CMF therapy in $B R C A 1$-related $\mathrm{BC}$ was also described by Byrski et al. [70].

Several investigators analyzed the use of taxane-containing schemes. Byrski et al. [70] observed low rate of pCR in patients with $B R C A 1$-mutated $B C$ receiving neoadjuvant combination of doxorubicin and docetaxel. Moiseyenko et al. [74] reported lack of response of chemonaive triple negative BRCA1-linked BC to the epirubicin-docetaxel doublet. Wysocki et al. [75] genotyped 19 non-responders to docetaxel and revealed as many as 5 (26\%) BRCA1 carriers. Kriege et al. [76] confirmed poor efficacy of docetaxel in $B R C A 1$ carriers, while $B R C A 2$-related $B C$ did not fare worse as compared to sporadic controls. It appears, that the preclinical and clinical evidence warning against the early use of taxanes for the treatment of BRCA1-related subtype of BC has already achieved a critical threshold; probably, specifically designed retrospective studies assessing BRCA1 status in distinct categories of taxane users may accelerate further understanding of this issue [77].

The experience of the use of single-agent cisplatin for the treatment of hereditary $\mathrm{BC}$ is still limited to BRCA1 carriers. Byrski et al. [70] reported 10/12 (83\%) pCR in patients undergoing neoadjuvant treatment. Silver et al. [78] used cisplatin for the preoperative treatment of triple-negative $\mathrm{BC}$; both $B R C A 1$ carriers included in the study demonstrated pCR. Moiseyenko et al. [74] observed major response to cisplatin in a patient whose metastatic $\mathrm{BC}$ was insensitive to the upfront anthracycline-taxane combination. The development of resistance to cisplatin may involve the appearance of 
Table 2 Drug sensitivity of breast-ovarian cancer syndrome related tumors: clinical evidence

\begin{tabular}{|c|c|}
\hline Study & Study design and main findings ${ }^{1}$ \\
\hline \multicolumn{2}{|r|}{ Breast cancer } \\
\hline $\begin{array}{c}\text { Kloos et al. [156]; Delagoge et al. } \\
\text { [65] }\end{array}$ & $\begin{array}{c}15 \text { BRCA1 carriers, } 5 \text { BRCA2 carriers and } 57 \text { matched controls were treated by anthracycline-based neoadjuvant } \\
\text { therapy. Objective responses in } 100 \%, 80 \%, 63 \% \text { and pCR in } 53 \%, 0 \% \text { and } 14 \% \text {, respectively. }\end{array}$ \\
\hline $\begin{array}{l}\text { Chappuis et al. [66]; Wong Wong } \\
\text { Keet et al. [71] }\end{array}$ & $\begin{array}{c}7 \text { BRCA1 and } 4 \text { BRCA2 carriers were treated by } 3-4 \text { cycles of anthracycline-based neoadjuvant therapy, } 10 \text { (91\%) } \\
\text { of them achieved cCR; pCR were documented in } 4(44 \%) \text { out of } 9 \text { evaluable cases. } 27 \text { patients served as } \\
\text { controls: } C C R \text { and pCR were detected in } 8(30 \%) \text { and } 1(4 \%) \text { patients, respectively. } \\
\text { These patients were followed for a median period of } 7 \text { years. Among complete clinical responders, only } 1 \\
\text { (17\%) out } 6 \text { BRCA1 carriers but } 3(75 \%) \text { out of } 4 \text { BRCA2 carriers died of breast cancer. }\end{array}$ \\
\hline Warner et al. [67] & $\begin{array}{c}\text { Rapid radiological disappearance and complete pathological response in a BRCA1 carrier treated by } \\
\text { neoadjuvant FEC. }\end{array}$ \\
\hline Petit et al. [72] & $\begin{array}{l}55 \text { triple-negative BC treated by neoadjuvant FEC. The subgroup of BRCA1 carriers showed lower pCR rate ( } 2 / \\
\qquad 12,17 \%) \text { than overall }(23 / 55,42 \%) .\end{array}$ \\
\hline Chrisanthar et al. [94] & $\begin{array}{c}\text { 2/3 (67\%) CHEK2 mutation carriers as compared to 8/104 (8\%) non-carriers progressed on neoadjuvant } \\
\text { epirubicin monotherapy for locally advanced breast cancer. }\end{array}$ \\
\hline Hubert et al. [68] & $\begin{array}{l}15 \text { BRCA1 and } 7 \text { BRCA2 stage III breast cancers were treated by anthracycline-based neoadjuvant therapy. cCR } \\
\text { in } 6 / 15(40 \%) \text { and } 1 / 7(14 \%), p C R \text { in } 2 / 15(13 \%) \text { and } 0 \text { patients, respectively. }\end{array}$ \\
\hline Melichar et al. [157] & $\begin{array}{c}\text { Case report on } 2 \text { related } B R C A 1 \text { carriers, whose tumor demonstrated } \mathrm{pCR} \text { upon dose dense } A C \text { and sequential } \\
\text { weekly paclitaxel. }\end{array}$ \\
\hline Wysocki et al. [75] & 19 non-responders to docetaxel have been analyzed; $5(26 \%)$ of them turned out to be BRCA1 carriers. \\
\hline Fong et al. [102] & $\begin{array}{c}\text { Phase I study dose escalation study for olaparib. } 3 \text { BRCA2-related chemotherapy refractory breast cancer } \\
\text { patients were evaluable for the treatment efficacy; } 1 \text { OR and } 1 \text { SD were observed. No responses in BRCA- } \\
\text { mutation-negative cases included in the study. }\end{array}$ \\
\hline
\end{tabular}

Fourquet et al. [69] Higher rate of cCR to anthracycline-based neoadjuvant therapy in BRCA1/2-carriers (15/33, 46\%) vs. non carriers $(7 / 41,17 \%)$

Huang et al. [80] Case report: metastatic breast cancer in a BRCA2-carrier was treated by several regimens of high dose therapy (epirubicin, alkylating agents, cisplatin, other cytotoxic drugs); CR with duration of $11+$ years was observed.

Kriege et al. [73] $\quad 93$ BRCA1 and 28 BRCA2 carriers received $1^{\text {st }}$-line chemotherapy (mainly anthracycline-based or CMF (CMF-like)) for the treatment of metastatic disease. Sporadic cases $(n=121)$ were used as a control. Marginally improved outcomes in BRCA1 carriers: OR: 66\% vs. 50\%; median PFS: 7.6 vs. 6.7 months; median OS: 15.0 vs. 13.6 months; significantly improved outcomes in BRCA2 carriers: OR: $89 \%$ vs. 50\%; median PFS: 11.4 vs. 6.7 months; median OS: 19.3 vs. 13.6 months.

\begin{tabular}{|c|c|}
\hline Rhiem et al. [158] & $\begin{array}{l}\text { Case report: major response of heavily pretreated metastatic BRCA1-related cancer to the combination of } \\
\text { cisplatin and gemcitabine, with the duration }>6 \text { months. }\end{array}$ \\
\hline Vollebergh et al. [81] & $\begin{array}{l}\text { Long term outcome of high dose therapy (carboplatin, thiotepa and cyclophosphamide) is analyzed in } 40 \\
\text { patients with metastatic breast cancer. } 6 \text { patients remained on complete remission at the time of the analysis } \\
(56+-150+\text { months); all these } 6 \text { patients demonstrated chromosomal imbalances characteristic for BRCA7- } \\
\text { related cancers. Complete long term responders included } 1 \text { out of } 2 \text { BRCA1- and } 1 \text { out of } 2 \text { BRCA2-carriers. }\end{array}$ \\
\hline Byrski et al. $[70,159,160]$ & $\begin{array}{c}102 \text { BRCA1 carriers treated by neoadjuvant chemotherapy. PCR in 1/14 (7\%) women receiving CMF, 2/25 (8\%) } \\
\text { patients exposed to doxorubicin and docetaxel, } 11 / 51 \text { (22\%) cases treated by AC or FAC, 10/12 (83\%) women } \\
\text { receiving cisplatin. }\end{array}$ \\
\hline Moiseyenko et al. [74] & $\begin{array}{l}\text { Case-report: lack of response of a chemonaive BRCA1-related cancer to the } 1^{\text {st }} \text { line epirubicin-docetaxel } \\
\text { combination, than major response to the } 2^{\text {nd }} \text { line single-agent cisplatin. }\end{array}$ \\
\hline Silver et al. [78] & $\begin{array}{c}28 \text { stage II or III triple-negative breast cancers were treated by } 4 \text { cycles of neoadjuvant cisplatin monotherapy. } \\
\text { Two BRCA1-carriers were included in the study, and both achieved pCR. }\end{array}$ \\
\hline Kriege et al. [76] & $\begin{array}{l}32 \text { BRCA1 carriers, } 13 \text { BRCA2 carriers and } 95 \text { controls treated by taxane monotherapy or taxane-trastuzumab } \\
\text { combination. Inferior results in BRCA1 carriers (OR rate = } 23 \% \text { vs. 38\%; PD in } 60 \% \text { vs. 19\%; median PFS = } 2.2 \text { vs. } \\
4.9 \text { months); this difference retained significance only in hormone receptor-negative cases, while hormone } \\
\text { receptor-positive tumors showed similar response rates and PFS. BRCA2 carriers: higher OR rate ( } 89 \% \text { vs. 38\%), } \\
\text { similar median PFS ( } 7.1 \text { vs. } 5.7 \text { months). }\end{array}$ \\
\hline Tutt et al. [82] & $\begin{array}{c}\text { BRCA1- and BRCA2-related metastatic breast cancers, with at least } 1 \text { prior chemotherapy regimen, treated by } \\
\text { high-dose }(n=27) \text { or low-dose }(n=27) \text { olaparib. OR in } 41 \% \text { and } 22 \% \text {; SD in } 44 \% \text { and } 44 \% \text {; median PFS = 5.7 } \\
\text { and } 3.8 \text { months. }\end{array}$ \\
\hline Sokolenko et al. [104] & $\begin{array}{l}5 \text { BLM-related breast cancers treated by conventional neoadjuvant chemotherapy; } 3 \text { patients showed nearly } \\
\text { complete pathologic response, and } 2 \text { remaining women demonstrated partial response. }\end{array}$ \\
\hline
\end{tabular}




\section{Table 2 Drug sensitivity of breast-ovarian cancer syndrome related tumors: clinical evidence (Continued)}

Cass et al. [83]

34 BRCA carriers (22 BRCA1 and 12 BRCA2) vs. 37 non-carriers were included in the study; 29 vs. 25 had stage III-IV disease and were therefore considered for the analysis of treatment outcome; 22 vs. 18 received paclitaxel plus carboplatin, and 7 vs. 7 were treated by cyclophosphamide plus carboplatin. BRCA1/2 carriers demonstrated higher OR rate (21/24 (88\%) vs. 9/19 (47\%)) and longer median OS (91 vs. 54 months) than noncarriers.

\begin{tabular}{|c|c|}
\hline Tan et al. [84] & $\begin{array}{c}\text { Therapy response was compared in } 22 \text { BRCA carriers (17 BRCA1 and } 5 \text { BRCA2) vs. } 44 \text { non carriers matched by } \\
\text { stage, histological subtype, age at diagnosis and year at diagnosis. Higher sensitivity to platinum-based therapy } \\
\left.\left.\left.\text { in the } 1^{\text {st }} \text { line (OR: } 96 \% \text { vs. } 59 \% \text {; CR: } 82 \% \text { vs. } 43 \%\right), 2^{\text {nd }} \text { line ( } 92 \% \text { vs. } 41 \%\right) \text { and } 3^{\text {rd }} \text { line treatment (100\% vs. } 14 \%\right) \\
\text { longer median OS ( } 8.4 \text { vs. } 2.9 \text { years). }\end{array}$ \\
\hline Fong et al. [102] & $\begin{array}{l}\text { Phase I study dose escalation study for olaparib. } 15 \text { BRCA-related (14 BRCA1 and } 1 \text { BRCA2) chemotherapy } \\
\text { refractory ovarian cancer patients were evaluable for treatment efficacy; } 8 \text { (53\%) OR and } 1 \text { (7\%) SD were } \\
\text { observed. No responses in BRCA-mutation-negative cases included in the study. }\end{array}$ \\
\hline Leunen et al. [161] & $\begin{array}{l}6 \text { patients with relapsed BRCA-related ovarian cancer, treated by multiple lines of therapy including dose-dense } \\
\text { paclitaxel-carboplatin; all patients responded to the therapy; median OS }=37 \text { months as compared to } 18 \\
\text { months in the historical control. }\end{array}$ \\
\hline Melichar et al. [86] & $\begin{array}{l}\text { Case report on a BRCA1-related ovarian cancer relapsed after prolonged post-surgical paclitaxel-carboplatin } \\
\text { therapy; each of } 4 \text { consequent relapses showed complete response to paclitaxel-cisplatin combination. }\end{array}$ \\
\hline Audeh et al. [87] & $\begin{array}{c}\text { BRCA1- and BRCA2-related recurrent ovarian cancers, with at least } 1 \text { prior chemotherapy regimen, treated by } \\
\text { high-dose }(\mathrm{n}=33 \text { ) or low-dose }(\mathrm{n}=24) \text { olaparib. OR in } 33 \% \text { and } 15 \% ; \text { SD in } 36 \% \text { and } 29 \% \text {; median duration } \\
\text { of response }=290 \text { and } 269 \text { days. }\end{array}$ \\
\hline Fong et al. [88] & $\begin{array}{l}\text { Phase I dose escalation and single-stage expansion trial for olaparib, given to } 50 \text { patients (including } 41 \text { BRCA1 } \\
\text { and } 7 \text { BRCA2 carriers) with advanced ovarian cancer, previously treated by platinum based therapy. OR in } 20 \\
(40 \%) \text { and SD in } 3(6 \%) \text { patients. Median duration of response }=28 \text { weeks. Strong correlation with platinum } \\
\text { sensitivity of the disease. }\end{array}$ \\
\hline Moiseyenko et al. [74] & $\begin{array}{c}\text { Complete clinical response and nearly-complete pathological response of bulky tumor treated by } 5 \text { cycles of } \\
\text { single-agent cisplatin. }\end{array}$ \\
\hline Vencken et al. [85] & $\begin{array}{l}93 \text { BRCA1-related, } 13 \text { BRCA2-related and } 222 \text { sporadic cancers analyzed for response to the } 1^{\text {st }} \text { line } \\
\text { chemotherapy. CR or no evidence for disease: } 87 \%, 92 \% \text { and } 71 \% \text {, respectively; PD: } 2 \%, 0 \% \text { and } 15 \% \text {; median } \\
\text { PFS: } 2.1,5.6 \text { and } 1.3 \text { years; median OS: } 5.9,>10 \text { and } 2.9 \text { years. Similar response rates in patients receiving } \\
\text { combination of platinum and paclitaxel vs. those treated by platinum-based therapy without paclitaxel. }\end{array}$ \\
\hline
\end{tabular}

\section{Pancreatic cancer}

Chalasani et al. [98] Case report on a BRCA2-related pancreatic adenocarcinoma. $1^{\text {st }}$ line therapy included combination of gemcitabine with experimental alkylating agent, and resulted in a major tumor response. Then alkylating agent was discontinued due to toxicity, and PD was observed on single-agent gemcitabine. Experimental antiangiogenic drug was given in the $2^{\text {nd }}$ line without any effect. $3^{\text {rd }}$ line therapy included mitomycin $C$ plus capecitabine, and again led to a major tumor response.

\begin{tabular}{|c|c|}
\hline James et al. [99] & $\begin{array}{l}\text { Case report on a BRCA2-related, KRAS wild-type pancreatic adenocarcinoma. Prolonged SD (56+ months) upon } \\
\text { multiple lines of chemotherapy (combination of docetaxel, capecitabine and gemcitabine; then irinotecan } \\
\text { monotherapy; then irinotecan plus cetuximab; then mitomycin C plus oxaliplatin; then mitomycin C plus } \\
\text { irinotecan). }\end{array}$ \\
\hline Villarroel et al. [97] & $\begin{array}{l}\text { Case report on a PALB2-related pancreatic adenocarcinoma, which progressed under } 1^{\text {st }} \text { line single-agent } \\
\text { gemcitabine, but showed major response after mitomycin } C \text { administration. Later mitomycin } C \text { was replaced } \\
\text { by cisplatin due to toxicity of the former. The patient remains asymptomatic for } 36+\text { months. }\end{array}$ \\
\hline Fogelman et al. [100] & $\begin{array}{l}\text { Case report on a BRCA2-related relapsed pancreatic adenocarcinoma, which rapidly regressed upon the } \\
\text { combination of gemcitabine and iniparib. Subsequent surgery revealed a complete pathologic response. }\end{array}$ \\
\hline \multicolumn{2}{|r|}{ Other cancers } \\
\hline Fong et al. [102] & $\begin{array}{l}\text { Phase I study dose escalation study for olaparib. } 1 \text { BRCA2-related castration-resistant prostate cancer patient } \\
\text { was included in the study; he demonstrated significant, durable marker response as well as resolution of bone } \\
\text { metastases. No responses in BRCA-mutation-negative cases. }\end{array}$ \\
\hline Moule et al. [101] & $\begin{array}{c}\text { Case report: complete response lasting for } 10+\text { years in a BRCA2 carrier, whose advanced non-small cell lung } \\
\text { cancer was treated by the combination of mitomycin C, cisplatin and vincristine. }\end{array}$ \\
\hline Vesprini et al. [103] & $\begin{array}{c}\text { Case report describing a patient with metastatic BRCA2-related prostate cancer, who was treated by cisplatin } \\
\text { after becoming insensitive to androgen ablation. Cisplatin therapy resulted in normalization of prostate-specific } \\
\text { antigen level and symptomatic relief for period of } 8 \text { months; docetaxel was administered after the disease } \\
\text { progression, and also led to an evident tumor response. }\end{array}$ \\
\hline
\end{tabular}

${ }^{1}$ Drug combinations: CMF: cyclophosphamide, methotrexate and fluorouracil; AC: doxorubicin and cyclophosphamide; FAC: 5-fluorouracil, doxorubicin and cyclophosphamide; FEC: 5-fluorouracil, epirubicin and cyclophosphamide.

Treatment outcomes: OR: objective response; PR: partial response; CR: complete response; cCR: clinical complete response; pCR: pathological complete response; SD: stable disease; PD: progressive disease; PFS: progression-free survival; OS: overall survival. 
secondary mutations, which restore $B R C A 1$ reading frame and therefore function of the corresponding protein $[61,79]$. One may expect that the newly acquired $B R C A 1$ proficiency will result in sensitization of the cancer cells to estrogen antagonists and taxanes [74].

There are a few case reports on the extremely successful use of high dose chemotherapy in metastatic $B R C A$ related $B C$. Since $B R C A$-deficient $B C$ are particularly sensitive to DNA damaging agents, use of intensive cytotoxic treatment may provide additional benefit to this category of patients. Furthermore, high dose therapy is likely to counteract tumor adaptation to the drugs, e. g. to induce rapid killing of cancer cells and therefore decrease the probability of developing secondary $B R C A 1$-restoring mutations. It is also important to consider that $B R C A$-driven cancers are often characterized by young age at onset, i.e. the majority of these patients would retain sufficient health conditions to qualify for a risky medical intervention. Huang et al. [80] described a patient with metastatic $B R C A 2$-related $\mathrm{BC}$, who was treated by high dose chemotherapy and remains diseasefree for more than 11 years. Vollebergh et al. [81] presented long term outcomes for 40 metastatic BC patients treated by high dose chemotherapy. 6 patients remained on complete remission for $56+-150+$ months, and all these 6 patients demonstrated chromosomal imbalances characteristic for BRCA1-related cancers. Complete long term responders included 1 out of 2 BRCA1- and 1 out of 2 BRCA2-carriers.

The only prospective clinical trial specifically designed for $B R C A$ carriers evaluated the efficacy of the PARP inhibitor olaparib (AZD2281, KU0059436) [82]. The study included metastatic breast cancer patients, who progressed on the standard chemotherapy schemes. When olaparib was given $400 \mathrm{mg}$ twice daily, objective response and disease stabilization were observed in 11/ 27 (41\%) and 12/27 (44\%) patients, respectively. Median progression-free survival approached to 5.7 months.

In agreement with preclinical findings, cisplatin and olaparib clearly outperform conventional treatment schemes when administered to BRCA1-driven BC cases. However, both these drugs have limited duration of response, so their use may require the addition of other anticancer agents $[31,33,38,39,59]$.

\section{Ovarian cancer}

$B R C A$-deficiency in cancer cell can be caused either by germ-line mutation followed by the "second hit", or by somatic inactivation of the $B R C A 1$ gene. $B R C A$-inactive tumors constitute the minority of breast cancers (up to $10-15 \%$ ), and are usually accumulated among family history positive or triple-negative cases. In contrast to $\mathrm{BC}$, the majority of ovarian carcinomas have signs of $B R C A$ inactivation, commonly defined in the literature as "BRCAness" $[9,15]$. Frequent BRCA-deficiency in OC appears to be a plausible explanation of the clinical success of platinum-based schemes in the treatment of this disease.

Three studies compared response to the standard chemotherapeutic regimens in $B R C A 1 / 2$ - mutated vs. sporadic OC cases [83-85]. These reports provide consistent evidence for higher sensitivity of $B R C A$-driven $\mathrm{OC}$ to platinum-containing treatments as compared to the mutation-negative tumors. Interestingly, prolonged tumor responses were documented both for taxane-free schemes and for the combination of platinating drugs with paclitaxel [83-86].

Two independent large trials evaluated the efficacy of olaparib in BRCA-mutated OC patients, who experienced prior chemotherapy $[87,88]$. Audeh et al. [87] observed objective response in $33 \%$ and stable disease in $36 \%$ of women receiving olaparib at dose $400 \mathrm{mg}$ twice daily. Fong et al. [88] reported tumor response in $40 \%$ and disease stabilization in 6\% patients, respectively; as expected, higher efficacy of olaparib was documented in those cases, which retained sensitivity to platinum-based therapy.

\section{Other genes and other tumors}

Hereditary $B C$ research led to identification of several genes other than BRCA1 and BRCA2. CHEK2 appears to be the most studied gene of this class. It confers elevated risk of breast cancer, while its heterozygous occurrence among ovarian cancer patients is not elevated $[89,90]$. CHEK2-mutated BC frequently express estrogen receptor [91,92]. Inactivation of CHEK2 by RNA-interference increased cell sensitivity to PARP inhibition [93]. The only available clinical observation describes $\mathrm{BC}$ progression in 2 out of 3 CHEK2 carriers, who were treated by neoadjuvant single-agent epirubicin, while this outcome was rare $(8 / 104,8 \%)$ in the non-carriers [94].

PALB2 (Partner And Localizers of BRCA2) has been proven to cause breast and pancreatic hereditary cancer $[95,96]$. In agreement with $B R C A 2$-related function of the $P A L B 2$, pancreatic cancer xenografts obtained from a PALB2 carrier demonstrated pronounced sensitivity to cisplatin and mitomycin C [97]. Importantly, excellent concordance between in vitro and clinical data was observed for this patient: his poorly differentiated ductal adenocarcinoma of the pancreas failed standard gemcitabine therapy, but demonstrated durable tumor response after mitomycin $\mathrm{C}$ or cisplatin administration [97]. Increased drug sensitivity of pancreatic tumors obtained from BRCA2 carriers was described in several other case reports [98-100]. Therefore, hereditary pancreatic cancers have clearly more favorable pattern of drug response as compared to sporadic cases. Similarly, excellent treatment effect lasting for more than 10 years was documented for BRCA2-related advanced lung 
cancer, which was treated by mitomycin $C$, cisplatin, and vincristine [101]. Another BRCA2 carrier, who suffered from castration-resistant prostate cancer, showed durable marker response and resolution of bone metastases after the administration of olaparib [102]. Vesprini et al. [103] have described a case of metastatic BRCA2related prostate cancer, which was treated by cisplatin after becoming insensitive to androgen ablation. This therapy resulted in normalization of prostate-specific antigen level and symptomatic relief for period of 8 months; docetaxel was administered after the disease progression, and also led to an evident tumor response.

Sokolenko et al. [104] have recently revealed a role of $B L M$ gene mutations in hereditary predisposition to breast cancer. This study included 5 patients treated by conventional neoadjuvant therapy; nearly complete pathological response was observed in 3 cases, while the remaining 2 women showed partial reduction of the tumor mass.

Preclinical data suggest specific drug sensitivity pattern for the cells with inactivated $N B N$ (NBS1) and BRIP1 (FANCJ, BACH1) genes [29,93]. It may turn to be difficult to validate these findings in the clinical setting, due to rarity and population-specific distribution of mutations in the mentioned genes.

\section{Hereditary non-polyposis colorectal cancer}

Hereditary non-polyposis colorectal cancer (HNPCC) is caused by germ-line mutations in $M L H 1, M S H 2, P M S 2$ and MSH6 genes. Virtually all tumors from HNPCC mutation carriers are characterized by the defect of mismatch repair (MMR), which is manifested by so-called high-level microsatellite instability (MSI-H). MSI-H occurs in up to $15 \%$ of colorectal cancers (CRC), however the majority of the microsatellite-unstable carcinomas are sporadic; hereditary CRC constitute approximately one fifth of MSI-H cases and account for only $2-3 \%$ of the total CRC incidence. Mutations in HNPCC-related genes may also predispose to a number of non-colonic tumors, including endometrial, gastric, urothelial, ovarian and some other neoplasms [105,106].

Given the rarity of hereditary CRC and the requirement of expensive multigene test for its definite diagnosis, the collection of clinical series for this disease represents a challenge. Instead, there is an intensive research focusing on MSI-H tumors as a distinct CRC entity; although sporadic and hereditary MSI-H CRC tumors share essential bioclinical features, many experts warn against combined analysis of these two tumor subsets. It is emphasized, that while hereditary CRC affect relatively young subjects, sporadic MSI-H cases are accumulated among elderly patients. Hereditary CRC arise due to mutational inactivation of the $M L H 1$, MSH2, PMS2 or MSH6; sporadic MSI-H tumors are usually driven by methylation of the $M L H 1$ gene promoter that may be a consequence of wide-spread abnormalities of epigenetic regulation ("methylator phenotype"). For unknown reason, $B R A F$ mutations occur only in sporadic but not in hereditary MSI-H tumors [106,107].

Although MSI-H tumors tend to be poorly differentiated, they are usually characterized by favorable disease course. In particular, MSI-H tumors show relatively low relapse rates after potentially curative surgery $[108,109]$; in accordance with this, only $4 \%$ of advanced CRC have MSI-H phenotype [110]. As result, MSI-H cases are exceptionally rare in trials involving metastatic CRC, therefore the direct clinical assessment of their chemosensitivity is highly complicated. The majority of treatment response data for MSI-H cases is derived from the adjuvant trials, where the reliable discrimination between prognostic and predictive significance of a given parameter is not always possible. Another critical issue concerns technical aspects of determination of microsatellite instability. The existing approaches for detection of MSI-H phenotype are not fully standardized and may be a subject of significant interlaboratory variations [111]. In particular, there is a debate concerning the inclusion of dinucleotide microsatellite markers in the "Bethesda panel", which is frequently used for MSI$\mathrm{H}$ diagnosis [112]. Many opinion leaders insist, that only mononucleotide markers (e.g., BAT26) allow to differentiate between true MSI-H and irrelevant mutational noise; hence, consideration of dinucleotide loci may increase the frequency of false-positive MSI-H detection and further compromise the conclusions of clinical trials [111].

Sensitivity of MMR-deficient cells to various anticancer drugs has been a subject of multiple laboratory studies. It is important to acknowledge, that naturally occurring MSI-H cancer cells have highly increased mutation rate and therefore accumulate significant number of "secondary" genetic lesions; depending of the spectrum of the target genes, these secondary lesions may substantially modify the response to treatment modalities [110,113]. Furthermore, inactivation of distinct MMR genes, e.g. $M S H 2$ and $M L H 1$, may result in distinct patterns of chemosensitivity [114].

Most of preclinical studies point at resistance of MSI$\mathrm{H}$ cells to 5-fluorouracil (5-FU) [110,115]. MSI-H status is also associated with low sensitivity to cisplatin, carboplatin, 6-thioguanine, however these compounds are anyway not engaged in routine CRC treatment [110,115-117]. While MMR-deficiency is associated with non-response to cisplatin and carboplatin, the third platinating drug, oxaliplatin, does not require functional MMR for its action [118]. Several studies have demonstrated specific sensitivity of MSI-H cells to irinotecan; it has been shown, that the response to topoisomerase I 
poisons may be mediated by the presence of secondary mutations in the double strand break response genes MRE11 and RAD50 [113]. Screen of the library of cytotoxic drugs has identified methotrexate as selective inhibitor of MSH2-deficient cells; MLH1-defective cells did not show specific sensitivity to this compound [114]. Martin et al. [119,120] have recently identified PINK1 kinase and several DNA polymerases as potential targets in cells with mutated MMR genes.

There is a good consensus in the literature that MSI$\mathrm{H}$ CRC patients do not benefit from 5-fluorouracil based adjuvant therapy [121]. Some reports have suggested even worse outcome in treated vs. non-treated patients; it is speculated that ineffective adjuvant therapy may compromise natural immune response to MSI-H cells $[110,122,123]$. One of the adjuvant patient series specifically included hereditary CRC cases, and also demonstrated lack of benefit from 5-fluorouracil [124]. Given an improved prognosis of MSI-H tumors, it is generally agreed that adjuvant therapy should be omitted for the stage II microsatellite unstable CRC $[110,125,126]$. Combination of 5-fluorouracil with oxaliplatin has been recently incorporated in the guidelines for adjuvant treatment of stage III CRC; as only a few MSI-H patients with follow-up are currently available, it is impossible to draw conclusions from the existing data sets $[127,128]$. Trials with irinotecan did not qualify this drug for the use in adjuvant setting; however, the analysis of subset of patients with MSI-H has demonstrated, that this specific category of CRC patients may benefit from addition of irinotecan to fluorouracil and leucovorin [129].

Data on the use of chemotherapy for advanced MSI-H CRC are limited by a few small studies. Liang et al. [130] and Brueckl et al. [131] reported improved response of microsatellite unstable CRC to the 5-fluorouracil-based therapy. There is conflicting information regarding the role of MSI status in determining response to the combination of 5-fluorouracil and oxaliplatin combination [132-134]. Several reports suggested increased response rate of MSI-H CRC to irinotecan [135-137], although this statement was disputed by the recent study of Kim et al. [138].

Burn et al. [139] analyzed the effect of aspirin and resistant starch, given either alone or in combination, on the occurrence of colorectal neoplasia in the $M L H 1$, MSH2 or MSH6 mutation carriers. Despite encouraging preclinical and epidemiological evidence, neither of these compounds influenced the risk of adenoma formation during the four years of the study.

\section{Familial adenomatous polyposis}

Familial adenomatous polyposis (FAP) is manifested by multiple polyps, which cause severe gastrointestinal symptoms and frequently progress into cancer lesions.
Classical FAP is caused by a dominant germ-line mutation of the $A P C$ gene. Some patients bear an attenuated form of this disease; mild manifestation of FAP may indicate the involvement of another genetic lesion, i.e. homozygous inactivation of MUTYH gene [140]. Development of colonic adenomas usually involves activation of cyclooxygenase 2. Clinical trial involving the specific inhibitor of this enzyme, celecoxib (Onsenal), demonstrated $28 \%$ reduction of the number of polyps and $30.7 \%$ reduction of the sum of polyp diameters in patients receiving this drug at $400 \mathrm{mg}$ twice daily for 6 months [141]. Based on the results of this trial, celecoxib has been approved for the treatment of FAP. However the safety of its long term-use is questioned by reports revealing elevated rate of cardiovascular events in patients receiving therapeutically effective dose of the drug [142]. Earlier studies demonstrated beneficial effect of sulindac, a non-steroidal anti-inflammatory drug; the results of these trials may be revisited, given that the main adverse effect of this drug, i.e. gastrointestinal toxicity, is medically manageable [143].

\section{Hereditary medullary thyroid cancer}

Hereditary medullary thyroid cancer (MTC) is caused by germ-line mutation in RET tyrosine kinase. It can be a part of multiple endocrine neoplasia (MEN) type 2A (MEN2A) or type 2B (MEN2B) syndromes, or manifest as a single-organ lesion (familial medullary thyroid cancer, FMTC) [144]. A novel multitargeted tyrosine kinase inhibitor vandetanib (ZD6474, Zactima) demonstrates specific activity against mutated RET and inhibits growth of RET-transformed cancer cells [145]. A clinical trial involving 30 patients with hereditary MTC, who received $300 \mathrm{mg}$ vandetanib daily, demonstrated objective tumor response in 6/30 (20\%) and disease stabilization for more than 24 weeks in $16 / 30$ (53\%) cases, respectively [146]. Precise measurement of the change of tumor size revealed the reduction of the lesions in $25 / 30$ (83\%) patients; the estimated median progression-free survival approached to 27.9 months [146]. Comparable results were obtained in another trial, which utilized 100 mg daily dosage of this drug [147].

\section{Sporadic phenocopies of hereditary cancers}

Hereditary neoplasms make relatively little contribution in the total cancer incidence. Nevertheless, advances in the treatment of this category of tumors may have broader practical implications, as many sporadic tumors develop phenotype similar to hereditary cancers. This issue was particularly intensively discussed in breast cancer research, owing to substantial overlap between $B R C A 1$-related and triple-negative BC [14]. Given that $B R C A 1$ may be inactivated not only by germ-line but also by somatic alterations, several investigations suggested to use BRCA1 expression as predictive marker of response to platinum-based and taxane-based therapy 
[78,148-152]. Other approaches are based on the detection of consequences of either BRCA deficiency or other critical defects of homologous recombination; in particular, it has been observed that tumors with presumably impaired repair of DNA double-strand breaks show characteristic pattern of acquired mutations [153,154]. Similarly to BRCA1, the mutations of RET oncogene are observed not only in hereditary, but also in sporadic medullary thyroid carcinomas; it is expected, that at least a subset of RET-driven non-hereditary MTC should respond to vandetanib therapy [144]. While for some tumor types clinical experience is translated from familial cancers to their phenocopies, the reverse flow is observed in colorectal cancer research; as already mentioned above, virtually all data on drug response have been obtained not on a genuine hereditary CRC, but on its phenocopy, i.e. MSI-H tumors; this limitation has to be considered by medical oncologists $[106,107]$.

\section{Conclusions and perspectives}

Patients with hereditary tumors often benefit from distinct drugs as compared to sporadic cases. The detection of cancer-predisposing germ-line mutations among the participants of clinical trials has rarely been considered, due to significant cost of genetic testing. Given the rapidly increasing accessibility of DNA analysis, it is foreseen that a large number of germ-line mutation carriers will be included in forthcoming trials and/or identified within retrospective collections of biological material. The analysis of correlations between genotype and drug response may substantially improve treatment outcomes, both for hereditary cancer patients and for subjects bearing phenocopies of familial tumors.

\section{Abbreviations \\ AC: doxorubicin and cyclophosphamide; BC: breast cancer; CMF: cyclophosphamide, methotrexate and fluorouracil; cCR: clinical complete response; CR: complete response; CRC: colorectal cancer; FAC: 5-fluorouracil, doxorubicin and cyclophosphamide; FAP: familial adenomatous polyposis; FEC: 5-fluorouracil, epirubicin and cyclophosphamide; HNPCC: hereditary non-polyposis colorectal cancer; HR: homologous recombination; MMR: mismatch repair; MTC: medullary thyroid cancer; $\mathrm{MSI}-\mathrm{H}$ : high-level microsatellite instability; OC: ovarian cancer; OR: objective response; OS: overall survival; PARP: poly (ADP-ribose) polymerase; pCR: pathological complete response; PD: progressive disease; PFS: progression-free survival; PR: partial response; SD: stable disease.}

\section{Acknowledgements}

This work has been supported by the Russian Federation for Basic Research (grants 10-04-92110, 10-04-92601, 11-04-00227), the Federal Agency for Science and Innovations (contract 02.740.11.0780), the Commission of the European Communities (grant PITN-GA-2009-238132) and the Government of Moscow (grant 15/11).

\section{Author details}

${ }^{1}$ Laboratory of Molecular Oncology, N.N. Petrov Institute of Oncology, St.Petersburg, 197758, Russia. ${ }^{2}$ Department of Oncology, St.-Petersburg Medical Academy for Postgraduate Studies, St.-Petersburg, 191015, Russia. ${ }^{3}$ Department of Medical Genetics, St.-Petersburg Pediatric Medical Academy, St.-Petersburg, 194100, Russia.

\section{Authors' contributions}

Both authors contributed to the literature search, data analysis and manuscript preparation. Both authors read and approved the final manuscript.

\section{Competing interests}

The authors declare that they have no competing interests.

Received: 1 March 2011 Accepted: 6 August 2011

Published: 6 August 2011

\section{References}

1. Bermejo-Pérez MJ, Márquez-Calderón S, Llanos-Méndez A: Effectiveness of preventive interventions in BRCA1/2 gene mutation carriers: a systematic review. Int J Cancer 2007, 121:225-231.

2. Domchek SM, Friebel TM, Singer CF, Evans DG, Lynch HT, Isaacs C, Garber JE, Neuhausen SL, Matloff E, Eeles R, Pichert G, Van t'veer L, Tung N, Weitzel JN, Couch FJ, Rubinstein WS, Ganz PA, Daly MB, Olopade Ol, Tomlinson G, Schildkraut J, Blum JL, Rebbeck TR: Association of riskreducing surgery in BRCA1 or BRCA2 mutation carriers with cancer risk and mortality. JAMA 2010, 304:967-975.

3. Kurian AW: BRCA1 and BRCA2 mutations across race and ethnicity: distribution and clinical implications. Curr Opin Obstet Gynecol 2010, 22:72-78.

4. Fasano J, Muggia F: Breast cancer arising in a BRCA-mutated background: therapeutic implications from an animal model and drug development. Ann Oncol 2009, 20:609-614.

5. Trainer AH, Lewis CR, Tucker K, Meiser B, Friedlander M, Ward RL: The role of BRCA mutation testing in determining breast cancer therapy. Nat Rev Clin Oncol 2010, 7:708-717.

6. van Beers EH, van Welsem T, Wessels LF, Li Y, Oldenburg RA, Devilee P, Cornelisse CJ, Verhoef S, Hogervorst FB, van't Veer LJ, Nederlof PM: Comparative genomic hybridization profiles in human BRCA1 and BRCA2 breast tumors highlight differential sets of genomic aberrations. Cancer Res 2005, 65:822-827.

7. Joosse SA, Brandwijk KI, Mulder L, Wesseling J, Hannemann J, Nederlof PM: Genomic signature of BRCA1 deficiency in sporadic basal-like breast tumors. Genes Chromosomes Cancer 2011, 50:71-81.

8. Lakhani SR, Manek S, Penault-Llorca F, Flanagan A, Arnout L, Merrett S, McGuffog L, Steele D, Devilee P, Klijn JG, Meijers-Heijboer H, Radice P, Pilotti S, Nevanlinna $H$, Butzow R, Sobol H, Jacquemier J, Lyonet DS, Neuhausen SL, Weber B, Wagner T, Winqvist R, Bignon YJ, Monti F, Schmitt F, Lenoir G, Seitz S, Hamman U, Pharoah P, Lane G, Ponder B, Bishop DT, Easton DF: Pathology of ovarian cancers in BRCA1 and BRCA2 carriers. Clin Cancer Res 2004, 10:2473-2481.

9. Turner N, Tutt A, Ashworth A: Hallmarks of 'BRCAness' in sporadic cancers. Nat Rev Cancer 2004, 4:814-819.

10. Bane AL, Beck JC, Bleiweiss I, Buys SS, Catalano E, Daly MB, Giles G, Godwin AK, Hibshoosh H, Hopper JL, John EM, Layfield L, Longacre T, Miron A, Senie R, Southey MC, West DW, Whittemore AS, Wu H, Andrulis IL, O'Malley FP: BRCA2 mutation-associated breast cancers exhibit a distinguishing phenotype based on morphology and molecular profiles from tissue microarrays. Am J Surg Pathol 2007, 31:121-128.

11. Stefansson OA, Jonasson JG, Johannsson OT, Olafsdottir K, Steinarsdottir M, Valgeirsdottir S, Eyfjord JE: Genomic profiling of breast tumours in relation to BRCA abnormalities and phenotypes. Breast Cancer Res 2009, 11:R47.

12. Yarden RI, Papa MZ: BRCA1 at the crossroad of multiple cellular pathways: approaches for therapeutic interventions. Mol Cancer Ther 2006, 5:1396-1404.

13. Holstege $H$, Joosse SA, van Oostrom CT, Nederlof PM, de Vries A, Jonkers J: High incidence of protein-truncating TP53 mutations in BRCA1-related breast cancer. Cancer Res 2009, 69:3625-3633.

14. Jaspers JE, Rottenberg S, Jonkers J: Therapeutic options for triple-negative breast cancers with defective homologous recombination. Biochim Biophys Acta 2009, 1796:266-280.

15. Hennessy BT, Timms KM, Carey MS, Gutin A, Meyer LA, Flake DD, Abkevich V, Potter J, Pruss D, Glenn P, Li Y, Li J, Gonzalez-Angulo AM, McCune KS, Markman M, Broaddus RR, Lanchbury JS, Lu KH, Mills GB: Somatic mutations in BRCA1 and BRCA2 could expand the number of 
patients that benefit from poly (ADP ribose) polymerase inhibitors in ovarian cancer. J Clin Oncol 2010, 28:3570-3576.

16. Gudmundsdottir K, Ashworth A: The roles of BRCA1 and BRCA2 and associated proteins in the maintenance of genomic stability. Oncogene 2006, 25:5864-5874.

17. Tutt $A$, Ashworth $A:$ Can genetic testing guide treatment in breast cancer? Eur J Cancer 2008, 44:2774-2780.

18. Hosey AM, Gorski JJ, Murray MM, Quinn JE, Chung WY, Stewart GE, James CR, Farragher SM, Mulligan JM, Scott AN, Dervan PA, Johnston PG, Couch FJ, Daly PA, Kay E, McCann A, Mullan PB, Harkin DP: Molecular basis for estrogen receptor alpha deficiency in BRCA1-linked breast cancer. J Natl Cancer Inst 2007, 99:1683-1694.

19. Atchley DP, Albarracin CT, Lopez A, Valero V, Amos Cl, GonzalezAngulo AM, Hortobagyi GN, Arun BK: Clinical and pathologic characteristics of patients with BRCA-positive and BRCA-negative breast cancer. J Clin Oncol 2008, 26:4282-4288.

20. DeLigio JT, Zorio DA: Early growth response 1 (EGR1): a gene with as many names as biological functions. Cancer Biol Ther 2009, 8:1889-1892.

21. Husain $A, H e$ G, Venkatraman ES, Spriggs DR: BRCA1 up-regulation is associated with repair-mediated resistance to cisdiamminedichloroplatinum(II). Cancer Res 1998, 58(6):1120-1123.

22. Bhattacharyya A, Ear US, Koller BH, Weichselbaum RR, Bishop DK: The breast cancer susceptibility gene BRCA1 is required for subnuclear assembly of Rad51 and survival following treatment with the DNA cross-linking agent cisplatin. J Biol Chem 2000, 275:23899-23903.

23. Lafarge S, Sylvain V, Ferrara M, Bignon YJ: Inhibition of BRCA1 leads to increased chemoresistance to microtubule-interfering agents, an effect that involves the JNK pathway. Oncogene 2001, 20:6597-6606.

24. Fedier A, Steiner RA, Schwarz VA, Lenherr L, Haller U, Fink D: The effect of loss of Brca1 on the sensitivity to anticancer agents in p53-deficient cells. Int J Oncol 2003, 22:1169-1173.

25. Quinn JE, Kennedy RD, Mullan PB, Gilmore PM, Carty M, Johnston PG, Harkin DP: BRCA1 functions as a differential modulator of chemotherapyinduced apoptosis. Cancer Res 2003, 63:6221-6228.

26. Tassone P, Tagliaferri P, Perricelli A, Blotta S, Quaresima B, Martelli ML, Goel A, Barbieri V, Costanzo F, Boland CR, Venuta S: BRCA1 expression modulates chemosensitivity of BRCA1-defective HCC1937 human breast cancer cells. Br J Cancer 2003, 88:1285-1291.

27. Samouëlian V, Maugard CM, Jolicoeur M, Bertrand R, Arcand SL, Tonin PN, Provencher DM, Mes-Masson AM: Chemosensitivity and radiosensitivity profiles of four new human epithelial ovarian cancer cell lines exhibiting genetic alterations in BRCA2, TGFbeta-RIl, KRAS2, TP53 and/or CDNK2A. Cancer Chemother Pharmacol 2004, 54:497-504.

28. van der Heijden MS, Brody JR, Gallmeier E, Cunningham SC, Dezentje DA, Shen D, Hruban RH, Kern SE: Functional defects in the fanconi anemia pathway in pancreatic cancer cells. Am J Pathol 2004, 165:651-657.

29. Bartz SR, Zhang Z, Burchard J, Imakura M, Martin M, Palmieri A, Needham R, Guo J, Gordon M, Chung N, Warrener P, Jackson AL, Carleton M, Oatley M, Locco L, Santini F, Smith T, Kunapuli P, Ferrer M, Strulovici B, Friend SH, Linsley PS: Small interfering RNA screens reveal enhanced cisplatin cytotoxicity in tumor cells having both BRCA network and TP53 disruptions. Mol Cell Biol 2006, 26:9377-9386.

30. Xing D, Orsulic S: A mouse model for the molecular characterization of brca1-associated ovarian carcinoma. Cancer Res 2006, 66:8949-8953.

31. Donawho CK, Luo Y, Luo Y, Penning TD, Bauch JL, Bouska JJ, BontchevaDiaz VD, Cox BF, DeWeese TL, Dillehay LE, Ferguson DC, GhoreishiHaack NS, Grimm DR, Guan R, Han EK, Holley-Shanks RR, Hristov B, Idler KB, Jarvis K, Johnson EF, Kleinberg LR, Klinghofer V, Lasko LM, Liu X, Marsh KC, McGonigal TP, Meulbroek JA, Olson AM, Palma JP, et al: ABT-888, an orally active poly(ADP-ribose) polymerase inhibitor that potentiates DNAdamaging agents in preclinical tumor models. Clin Cancer Res 2007, 13:2728-2737.

32. Rottenberg $\mathrm{S}$, Nygren AO, Pajic M, van Leeuwen FW, van der Heijden I, van de Wetering K, Liu X, de Visser KE, Gilhuijs KG, van Tellingen O, Schouten JP, Jonkers J, Borst P: Selective induction of chemotherapy resistance of mammary tumors in a conditional mouse model for hereditary breast cancer. Proc Natl Acad Sci USA 2007, 104:12117-12122.

33. Evers B, Drost $R$, Schut $E$, de Bruin $M$, van der Burg E, Derksen PW, Holstege H, Liu X, van Drunen E, Beverloo HB, Smith GC, Martin NM, Lau A, O'Connor MJ, Jonkers J: Selective inhibition of BRCA2-deficient mammary tumor cell growth by AZD2281 and cisplatin. Clin Cancer Res 2008, 14:3916-3925.

34. Shafee N, Smith CR, Wei S, Kim Y, Mills GB, Hortobagyi GN, Stanbridge EJ, Lee EY: Cancer stem cells contribute to cisplatin resistance in Brca1/p53mediated mouse mammary tumors. Cancer Res 2008, 68:3243-3250.

35. Hay T, Matthews JR, Pietzka L, Lau A, Cranston A, Nygren AO, DouglasJones A, Smith GC, Martin NM, O'Connor M, Clarke AR: Poly(ADP-ribose) polymerase- 1 inhibitor treatment regresses autochthonous Brca2/p53mutant mammary tumors in vivo and delays tumor relapse in combination with carboplatin. Cancer Res 2009, 69:3850-3855.

36. Santarosa M, Del Col L, Tonin E, Caragnano A, Viel A, Maestro R: Premature senescence is a major response to DNA cross-linking agents in BRCA1defective cells: implication for tailored treatments of BRCA1 mutation carriers. Mol Cancer Ther 2009, 8:844-854.

37. Tassone P, Di Martino MT, Ventura M, Pietragalla A, Cucinotto I, Calimeri T, Bulotta A, Neri P, Caraglia M, Tagliaferri P: Loss of BRCA1 function increases the antitumor activity of cisplatin against human breast cancer xenografts in vivo. Cancer Biol Ther 2009, 8:648-653.

38. Evers B, Schut E, van der Burg E, Braumuller TM, Egan DA, Holstege $H$, Edser P, Adams DJ, Wade-Martins R, Bouwman P, Jonkers J: A highthroughput pharmaceutical screen identifies compounds with specific toxicity against BRCA2-deficient tumors. Clin Cancer Res 2010, 16:99-108.

39. Drew $Y$, Mulligan EA, Vong WT, Thomas HD, Kahn S, Kyle $S$, Mukhopadhyay A, Los G, Hostomsky Z, Plummer ER, Edmondson RJ, Curtin NJ: Therapeutic potential of poly(ADP-ribose) polymerase inhibitor AG014699 in human cancers with mutated or methylated BRCA1 or BRCA2. J Natl Cancer Inst 2011, 103:334-346.

40. Kortmann U, McAlpine JN, Xue H, Guan J, Ha G, Tully S, Shafait S, Lau A Cranston AN, O'Connor MJ, Huntsman DG, Wang Y, Gilks CB: Tumor growth inhibition by olaparib in BRCA2 germline-mutated patientderived ovarian cancer tissue xenografts. Clin Cancer Res 2011, 17:783-791.

41. Yu VP, Koehler M, Steinlein C, Schmid M, Hanakahi LA, van Gool AJ, West SC, Venkitaraman AR: Gross chromosomal rearrangements and genetic exchange between nonhomologous chromosomes following BRCA2 inactivation. Genes Dev 2000, 14:1400-1406.

42. Moynahan ME, Cui TY, Jasin M: Homology-directed dna repair, mitomycin-c resistance, and chromosome stability is restored with correction of a Brca1 mutation. Cancer Res 2001, 61:4842-4850

43. van der Heijden MS, Brody JR, Dezentje DA, Gallmeier E, Cunningham SC, Swartz MJ, DeMarzo AM, Offerhaus GJ, Isacoff WH, Hruban RH, Kern SE: In vivo therapeutic responses contingent on Fanconi anemia/BRCA2 status of the tumor. Clin Cancer Res 2005, 11:7508-7515.

44. Yun J, Zhong Q, Kwak JY, Lee WH: Hypersensitivity of Brca1-deficient MEF to the DNA interstrand crosslinking agent mitomycin $C$ is associated with defect in homologous recombination repair and aberrant S-phase arrest. Oncogene 2005, 24:4009-4016.

45. Brodie SG, XU X, Qiao W, Li WM, Cao L, Deng CX: Multiple genetic changes are associated with mammary tumorigenesis in Brca1 conditional knockout mice. Oncogene 2001, 20:7514-7523.

46. Issaeva N, Thomas HD, Djureinovic T, Jaspers JE, Stoimenov I, Kyle S, Pedley N, Gottipati P, Zur R, Sleeth K, Chatzakos V, Mulligan EA, Lundin C, Gubanova E, Kersbergen A, Harris AL, Sharma RA, Rottenberg S, Curtin NJ, Helleday T: 6-thioguanine selectively kills BRCA2-defective tumors and overcomes PARP inhibitor resistance. Cancer Res 2010, 70:6268-6276.

47. Abbott DW, Freeman ML, Holt JT: Double-strand break repair deficiency and radiation sensitivity in BRCA2 mutant cancer cells. J Nat/ Cancer Inst 1998, 90:978-985.

48. Treszezamsky AD, Kachnic LA, Feng Z, Zhang J, Tokadjian C, Powell SN: BRCA1- and BRCA2-deficient cells are sensitive to etoposide-induced DNA double-strand breaks via topoisomerase II. Cancer Res 2007, 67:7078-7081.

49. Mullan PB, Quinn JE, Gilmore PM, McWilliams S, Andrews H, Gervin C, McCabe N, McKenna S, White P, Song YH, Maheswaran S, Liu E, Haber DA, Johnston PG, Harkin DP: BRCA1 and GADD45 mediated G2/M cell cycle arrest in response to antimicrotubule agents. Oncogene 2001, 20:6123-6131.

50. Chabalier C, Lamare C, Racca C, Privat M, Valette A, Larminat F: BRCA1 downregulation leads to premature inactivation of spindle checkpoint and confers paclitaxel resistance. Cell Cycle 2006, 5:1001-1007. 
51. Promkan M, Liu G, Patmasiriwat P, Chakrabarty S: BRCA1 modulates malignant cell behavior, the expression of survivin and chemosensitivity in human breast cancer cells. Int J Cancer 2009, 125:2820-2828.

52. Zhou C, Smith JL, Liu J: Role of BRCA1 in cellular resistance to paclitaxel and ionizing radiation in an ovarian cancer cell line carrying a defective BRCA1. Oncogene 2003, 22:2396-2404

53. Tassone P, Blotta S, Palmieri C, Masciari S, Quaresima B, Montagna M, D'Andrea E, Eramo OP, Migale L, Costanzo F, Tagliaferri P, Venuta S: Differential sensitivity of BRCA1-mutated HCC1937 human breast cancer cells to microtubule-interfering agents. Int J Oncol 2005, 26:1257-1263.

54. Zander SA, Kersbergen $\mathrm{A}$, van der Burg $\mathrm{E}$, de Water $\mathrm{N}$, van Tellingen $\mathrm{O}$, Gunnarsdottir S, Jaspers JE, Pajic M, Nygren AO, Jonkers J, Borst P, Rottenberg $\mathrm{S}$ : Sensitivity and acquired resistance of BRCA1;p53-deficient mouse mammary tumors to the topoisomerase I inhibitor topotecan. Cancer Res 2010, 70:1700-1710.

55. Rahden-Staroń I, Szumił M, Grosicka E, Kraakman van der Zwet M Zdzienicka MZ: Defective Brca2 influences topoisomerase I activity in mammalian cells. Acta Biochim Pol 2003, 50:139-144.

56. Bryant HE, Schultz N, Thomas HD, Parker KM, Flower D, Lopez E, Kyle S, Meuth M, Curtin NJ, Helleday T: Specific killing of BRCA2-deficient tumours with inhibitors of poly(ADP-ribose) polymerase. Nature 2005, 434:913-917.

57. Farmer $\mathrm{H}, \mathrm{McC}$ abe $\mathrm{N}$, Lord CJ, Tutt AN, Johnson DA, Richardson $\mathrm{TB}$, Santarosa M, Dillon KJ, Hickson I, Knights C, Martin NM, Jackson SP, Smith GC, Ashworth A: Targeting the DNA repair defect in BRCA mutant cells as a therapeutic strategy. Nature 2005, 434:917-921.

58. McCabe N, Lord CJ, Tutt AN, Martin NM, Smith GC, Ashworth A: BRCA2 deficient CAPAN-1 cells are extremely sensitive to the inhibition of Poly (ADP-Ribose) polymerase: an issue of potency. Cancer Biol Ther 2005, 4:934-936

59. Rottenberg $\mathrm{S}$, Jaspers JE, Kersbergen $A$, van der Burg E, Nygren $A O$, Zander SA, Derksen PW, de Bruin M, Zevenhoven J, Lau A, Boulter R, Cranston A, O'Connor MJ, Martin NM, Borst P, Jonkers J: High sensitivity of BRCA1-deficient mammary tumors to the PARP inhibitor AZD2281 alone and in combination with platinum drugs. Proc Natl Acad Sci USA 2008 105:17079-17084.

60. Goldberg MS, Xing D, Ren Y, Orsulic S, Bhatia SN, Sharp PA: Nanoparticlemediated delivery of siRNA targeting Parp1 extends survival of mice bearing tumors derived from Brca1-deficient ovarian cancer cells. Proc Natl Acad Sci USA 2011, 108:745-750.

61. Ashworth A: Drug resistance caused by reversion mutation. Cancer Res 2008, 68:10021-10023.

62. Underhill $\mathrm{C}$, Toulmonde $\mathrm{M}$, Bonnefoi $\mathrm{H}$ : A review of PARP inhibitors: from bench to bedside. Ann Oncol 2011, 22:268-279.

63. Narod SA: BRCA mutations in the management of breast cancer: the state of the art. Nat Rev Clin Oncol 2010, 7:702-707.

64. Foulkes WD, Goffin J, Brunet JS, Bégin LR, Wong N, Chappuis PO: Tamoxifen may be an effective adjuvant treatment for BRCA1-related breast cancer irrespective of estrogen receptor status. J Natl Cancer Inst 2002, 94:1504-1506.

65. Delaloge S, Pélissier P, Kloos I, Bressac de Paillerets B, Mathieu MC, Chompret A, Noguès $C$, Lortholary A, Piketty AC, Spielmann M: BRCA1linked breast cancer $(B C)$ is highly more chemosensitive than its BRCA2linked or sporadic counterparts. Ann Oncol 2002, 13(Suppl 5):34.

66. Chappuis PO, Goffin J, Wong N, Perret C, Ghadirian P, Tonin PN, Foulkes WD: A significant response to neoadjuvant chemotherapy in BRCA1/2 related breast cancer. J Med Genet 2002, 39:608-610.

67. Warner E, Trudeau M, Holloway C: Sensitivity of BRCA-1-related breast cancer to neoadjuvant chemotherapy: practical implications. Breast $J$ 2003, 9:507-508.

68. Hubert A, Mali B, Hamburger T, Rottenberg Y, Uziely B, Peretz T, Kadouri L: Response to neo-adjuvant chemotherapy in BRCA1 and BRCA2 related stage III breast cancer. Fam Cancer 2009, 8:173-177.

69. Fourquet A, Stoppa-Lyonnet D, Kirova YM, Sigal-Zafrani B, Asselain B, Institut Curie Breast Cancer Study Group; Institut Curie Breast Ovary Cancer Risk Study Group: Familial breast cancer: clinical response to induction chemotherapy or radiotherapy related to BRCA1/2 mutations status. Am J Clin Oncol 2009, 32:127-131.

70. Byrski T, Gronwald J, Huzarski T, Grzybowska E, Budryk M, Stawicka M, Mierzwa T, Szwiec M, Wisniowski R, Siolek M, Dent R, Lubinski J, Narod S: Pathologic complete response rates in young women with BRCA1- positive breast cancers after neoadjuvant chemotherapy. J Clin Oncol 2010, 28:375-379.

71. Wong Wong Keet A, Al-Rafae M, Chappuis PO, Brunet JS, Ghadirian P, Foulkes WD: Long-term outcome after neo-adjuvant chemotherapy for breast cancer in BRCA1/2 carriers. Int J Cancer 2009, 125:2236-2238.

72. Petit T, Wilt M, Rodier J, Muller D, Ghnassia J, Dufour P, Fricker J: Are BRCA1 mutations a predictive factor for anthracycline-based neoadjuvant chemotherapy response in triple-negative breast cancers? J Clin Oncol 2007, 25(Suppl):abstract 580.

73. Kriege M, Seynaeve C, Meijers-Heijboer H, Collee JM, Menke-Pluymers MB, Bartels CC, Tilanus-Linthorst MM, Blom J, Huijskens E, Jager A, van den Ouweland A, van Geel B, Hooning MJ, Brekelmans CT, Klijn JG: Sensitivity to first-line chemotherapy for metastatic breast cancer in BRCA1 and BRCA2 mutation carriers. J Clin Oncol 2009, 27:3764-3771.

74. Moiseyenko VM, Protsenko SA, Brezhnev NV, Maximov SY, Gershveld ED, Hudyakova MA, Lobeiko OS, Gergova MM, Krzhivitskiy PI, Semionov II, Matsko DE, lyevleva AG, Sokolenko AP, Sherina NY, Kuligina ESh, Suspitsin EN, Togo AV, Imyanitov EN: High sensitivity of BRCA1-associated tumors to cisplatin monotherapy: report of two cases. Cancer Genet Cytogenet 2010, 197:91-94.

75. Wysocki PJ, Korski K, Lamperska K, Zaluski J, Mackiewicz A: Primary resistance to docetaxel-based chemotherapy in metastatic breast cancer patients correlates with a high frequency of BRCA1 mutations. Med Sci Monit 2008, 14:SC7-SC10

76. Kriege M, Jager A, Hooning MJ, Huijskens E, Blom J, van Deurzen $\mathrm{CH}$, Bontenbal M, Collee JM, Menke-Pluijmers MB, Martens JW, Seynaeve C: The efficacy of taxane chemotherapy for metastatic breast cancer in BRCA1 and BRCA2 mutation carriers. Cancer 2011.

77. Imyanitov EN: Breast cancer therapy for BRCA1 carriers: moving towards platinum standard? Hered Cancer Clin Pract 2009, 7:8.

78. Silver DP, Richardson AL, Eklund AC, Wang ZC, Szallasi Z, Li Q, Juul N, Leong CO, Calogrias D, Buraimoh A, Fatima A, Gelman RS, Ryan PD, Tung NM, De Nicolo A, Ganesan S, Miron A, Colin C, Sgroi DC, Ellisen LW, Winer EP, Garber JE: Efficacy of neoadjuvant Cisplatin in triple-negative breast cancer. J Clin Oncol 2010, 28:1145-1153.

79. Swisher EM, Sakai W, Karlan BY, Wurz K, Urban N, Taniguchi T: Secondary BRCA1 mutations in BRCA1-mutated ovarian carcinomas with platinum resistance. Cancer Res 2008, 68:2581-2586.

80. Huang F, Kushner YB, Langleben A, Foulkes WD, Medscape: Eleven years disease-free: role of chemotherapy in metastatic BRCA2-related breast cancer. Nat Rev Clin Oncol 2009, 6:488-492.

81. Vollebergh MA, Nederlof PM, Wessels LF, Schmidt MK, Joosse SA, van Beers E, Froklage F, Holtkamp M, Schrama JG, Wesseling J, Hauptmann M, de Bruin M, Rodenhuis S, Linn SC: Predicting response to alkylating chemotherapy in breast cancer patients using array comparative genomic hybridization. Cancer Res 2009, 69(Suppl 1):abstract 6050 .

82. Tutt A, Robson M, Garber JE, Domchek SM, Audeh MW, Weitzel JN, Friedlander M, Arun B, Loman N, Schmutzler RK, Wardley A, Mitchell G, Earl H, Wickens M, Carmichael J: Oral poly(ADP-ribose) polymerase inhibitor olaparib in patients with BRCA1 or BRCA2 mutations and advanced breast cancer: a proof-of-concept trial. Lancet 2010, 376:235-244.

83. Cass I, Baldwin RL, Varkey T, Moslehi R, Narod SA, Karlan BY: Improved survival in women with BRCA-associated ovarian carcinoma. Cancer 2003, 97:2187-2195.

84. Tan DS, Rothermundt C, Thomas K, Bancroft E, Eeles R, Shanley S, ArdernJones A, Norman A, Kaye SB, Gore ME: "BRCAness" syndrome in ovarian cancer: a case-control study describing the clinical features and outcome of patients with epithelial ovarian cancer associated with BRCA1 and BRCA2 mutations. J Clin Oncol 2008, 26:5530-5536.

85. Vencken PM, Kriege M, Hoogwerf $D$, Beugelink $S$, van der Burg ME, Hooning MJ, Berns EM, Jager A, Collée M, Burger CW, Seynaeve C: Chemosensitivity and outcome of BRCA1- and BRCA2-associated ovarian cancer patients after first-line chemotherapy compared with sporadic ovarian cancer patients. Ann Oncol 2011, 22:1346-1352.

86. Melichar B, Fridrichová P, Tomsová M, Malírová E: Repeat chemosensitivity of epithelial ovarian carcinoma in a BRCA1 mutation carrier to paclitaxel/platinum combination chemotherapy. Eur I Gynaecol Oncol 2009, 30:323-325.

87. Audeh MW, Carmichael J, Penson RT, Friedlander M, Powell B, BellMcGuinn KM, Scott C, Weitzel JN, Oaknin A, Loman N, Lu K, Schmutzler RK, 
Matulonis U, Wickens M, Tutt A: Oral poly(ADP-ribose) polymerase inhibitor olaparib in patients with BRCA1 or BRCA2 mutations and recurrent ovarian cancer: a proof-of-concept trial. Lancet 2010, 376:245-251.

88. Fong PC, Yap TA, Boss DS, Carden CP, Mergui-Roelvink M, Gourley C, De Greve J, Lubinski J, Shanley S, Messiou C, A'Hern R, Tutt A, Ashworth A, Stone J, Carmichael J, Schellens JH, de Bono JS, Kaye SB: Poly(ADP)-ribose polymerase inhibition: frequent durable responses in BRCA carrier ovarian cancer correlating with platinum-free interval. J Clin Oncol 2010 28:2512-2519.

89. Weischer M, Bojesen SE, Ellervik C, Tybjaerg-Hansen A, Nordestgaard BG: CHEK2*1100delC genotyping for clinical assessment of breast cancer risk: meta-analyses of 26,000 patient cases and 27,000 controls. J Clin Oncol 2008, 26:542-548.

90. Suspitsin EN, Sherina NY, Ponomariova DN, Sokolenko AP, Iyevleva AG, Gorodnova TV, Zaitseva OA, Yatsuk OS, Togo AV, Tkachenko NN, Shiyanov GA, Lobeiko OS, Krylova NY, Matsko DE, Maximov SY, Urmancheyeva AF, Porhanova NV, Imyanitov EN: High frequency of BRCA1, but not CHEK2 or NBS1 (NBN), founder mutations in Russian ovarian cancer patients. Hered Cancer Clin Pract 2009, 7:5.

91. de Bock GH, Schutte M, Krol-Warmerdam EM, Seynaeve C, Blom J, Brekelmans $C T$, Meijers-Heijboer $H$, van Asperen CJ, Cornelisse CJ, Devilee P, Tollenaar RA, Klijn JG: Tumour characteristics and prognosis of breast cancer patients carrying the germline CHEK2*1100delC variant. J Med Genet 2004, 41:731-735.

92. Cybulski C, Huzarski T, Byrski T, Gronwald J, Debniak T, Jakubowska A, Górski B, Wokołrczyk D, Masojć B, Narod SA, Lubiński J: Estrogen receptor status in CHEK2-positive breast cancers: implications for chemoprevention. Clin Genet 2009, 75:72-78

93. McCabe N, Turner NC, Lord CJ, Kluzek K, Bialkowska A, Swift S, Giavara S, O'Connor MJ, Tutt AN, Zdzienicka MZ, Smith GC, Ashworth A: Deficiency in the repair of DNA damage by homologous recombination and sensitivity to poly(ADP-ribose) polymerase inhibition. Cancer Res 2006, 66:8109-8115.

94. Chrisanthar R, Knappskog S, Løkkevik E, Anker G, Østenstad B, Lundgren S, Berge EO, Risberg T, Mjaaland I, Maehle L, Engebretsen LF, Lillehaug JR, Lønning PE: CHEK2 mutations affecting kinase activity together with mutations in TP53 indicate a functional pathway associated with resistance to epirubicin in primary breast cancer. PLoS One 2008, 3:e3062.

95. Jones S, Hruban RH, Kamiyama M, Borges M, Zhang X, Parsons DW, Lin JC, Palmisano E, Brune K, Jaffee EM, lacobuzio-Donahue CA, Maitra A, Parmigiani G, Kern SE, Velculescu VE, Kinzler KW, Vogelstein B, Eshleman JR, Goggins M, Klein AP: Exomic sequencing identifies PALB2 as a pancreatic cancer susceptibility gene. Science 2009, 324:217.

96. Bogdanova N, Sokolenko AP, lyevleva AG, Abysheva SN, Blaut M, Bremer M, Christiansen H, Rave-Fränk M, Dörk T, Imyanitov EN: PALB2 mutations in German and Russian patients with bilateral breast cancer. Breast Cancer Res Treat 2011, 126:545-550.

97. Villarroel MC, Rajeshkumar NV, Garrido-Laguna I, De Jesus-Acosta A, Jones S, Maitra A, Hruban RH, Eshleman JR, Klein A, Laheru D, Donehower R, Hidalgo M: Personalizing cancer treatment in the age of global genomic analyses: PALB2 gene mutations and the response to DNA damaging agents in pancreatic cancer. Mol Cancer Ther 2011, 10:3-8.

98. Chalasani $P$, Kurtin $S$, Dragovich $T$ : Response to a third-line mitomycin $C$ (MMC)-based chemotherapy in a patient with metastatic pancreatic adenocarcinoma carrying germline BRCA2 mutation. JOP 2008, 9:305-308.

99. James E, Waldron-Lynch MG, Saif MW: Prolonged survival in a patient with BRCA2 associated metastatic pancreatic cancer after exposure to camptothecin: a case report and review of literature. Anticancer Drugs 2009, 20:634-8.

100. Fogelman DR, Wolff RA, Kopetz S, Javle M, Bradley C, Mok I, Cabanillas F, Abbruzzese JL: Evidence for the efficacy of Iniparib, a PARP-1 inhibitor, in BRCA2-associated pancreatic cancer. Anticancer Res 2011, 31:1417-1420.

101. Moule R, Sohaib A, Eeles R: Dramatic response to platinum in a patient with cancer with a germline BRCA2 mutation. Clin Oncol (R Coll Radiol) 2009, 21:444-447.

102. Fong PC, Boss DS, Yap TA, Tutt A, Wu P, Mergui-Roelvink M, Mortimer $P$, Swaisland H, Lau A, O'Connor MJ, Ashworth A, Carmichael J, Kaye SB, Schellens JH, de Bono JS: Inhibition of poly(ADP-ribose) polymerase in tumors from BRCA mutation carriers. N Engl J Med 2009, 361:123-134.
103. Vesprini D, Narod SA, Trachtenberg J, Crook J, Jalali F, Preiner J, Sridhar S, Bristow RG: The therapeutic ratio is preserved for radiotherapy or cisplatin treatment in BRCA2-mutated prostate cancers. Can Urol Assoc J 2011, 5:E31-E35.

104. Sokolenko AP, Iyevleva AG, Preobrazhenskaya EV, Mitiushkina NV, Abysheva SN, Suspitsin EN, Kuligina ESh, Gorodnova TV, Pfeifer W, Togo AV, Turkevich EA, Ivantsov OA, Voskresenskiy DV, Dolmatov GD, Bit-Sava EM, Matsko DE, Semiglazov VF, Fichtner I, Larionov AA, Kuznetsov SG, Antoniou AC, Imyanitov EN: High prevalence and breast cancer predisposing role of the BLM c.1642 C>T (Q548X) mutation in Russia. Int $J$ Cancer .

105. Boland CR, Goel A: Microsatellite instability in colorectal cancer. Gastroenterology 2010, 138:2073-2087.

106. Vilar E, Gruber SB: Microsatellite instability in colorectal cancer-the stable evidence. Nat Rev Clin Oncol 2010, 7:153-162.

107. Clark AJ, Barnetson R, Farrington SM, Dunlop MG: Prognosis in DNA mismatch repair deficient colorectal cancer: are all MSI tumours equivalent? Fam Cancer 2004, 3:85-91.

108. Popat S, Hubner R, Houlston RS: Systematic review of microsatellite instability and colorectal cancer prognosis. J Clin Oncol 2005, 23:609-618.

109. Guastadisegni C, Colafranceschi M, Ottini L, Dogliotti E: Microsatellite instability as a marker of prognosis and response to therapy: a metaanalysis of colorectal cancer survival data. Eur J Cancer 2010, 46:2788-2798.

110. Hewish M, Lord CJ, Martin SA, Cunningham D, Ashworth A: Mismatch repair deficient colorectal cancer in the era of personalized treatment. Nat Rev Clin Oncol 2010, 7:197-208.

111. Laghi L, Bianchi P, Malesci A: Differences and evolution of the methods for the assessment of microsatellite instability. Oncogene 2008, 27:6313-6321.

112. Perucho M: Correspondence re: C.R. Boland et al., A National Cancer Institute workshop on microsatellite instability for cancer detection and familial predisposition: development of international criteria for the determination of microsatellite instability in colorectal cancer. Cancer Res., 58: 5248-5257, 1998. Cancer Res 1999, 59:249-256.

113. Vilar E, Scaltriti M, Balmaña J, Saura C, Guzman M, Arribas J, Baselga J, Tabernero J: Microsatellite instability due to $\mathrm{hMLH} 1$ deficiency is associated with increased cytotoxicity to irinotecan in human colorectal cancer cell lines. Br J Cancer 2008, 99:1607-1612.

114. Martin SA, McCarthy A, Barber L, Burgess DJ, Parry S, Lord CJ, Ashworth A: Methotrexate induces oxidative DNA damage and is selectively lethal to tumour cells with defects in the DNA mismatch repair gene MSH2. EMBO Mol Med 2009, 1:323-337.

115. Valentini AM, Armentano R, Pirrelli M, Caruso ML: Chemotherapeutic agents for colorectal cancer with a defective mismatch repair system: the state of the art. Cancer Treat Rev 2006, 32:607-618.

116. Papouli E, Cejka P, Jiricny J: Dependence of the cytotoxicity of DNAdamaging agents on the mismatch repair status of human cells. Cancer Res 2004, 64:3391-3394.

117. Yamane K, Schupp JE, Kinsella TJ: BRCA1 activates a G2-M cell cycle checkpoint following 6-thioguanine-induced DNA mismatch damage. Cancer Res 2007, 67:6286-6292.

118. Fink $D$, Zheng $H$, Nebel S, Norris PS, Aebi S, Lin TP, Nehmé A, Christen RD, Haas M, MacLeod CL, Howell SB: In vitro and in vivo resistance to cisplatin in cells that have lost DNA mismatch repair. Cancer Res 1997, 57:1841-1845.

119. Martin SA, Hewish M, Sims D, Lord CJ, Ashworth A: Parallel high throughput RNA interference screens identify PINK1 as a potential therapeutic target for the treatment of DNA mismatch repair deficient cancers. Cancer Res 2011, 71:1836-1848.

120. Martin SA, McCabe N, Mullarkey M, Cummins R, Burgess DJ, Nakabeppu Y, Oka S, Kay E, Lord CJ, Ashworth A: DNA polymerases as potential therapeutic targets for cancers deficient in the DNA mismatch repair proteins MSH2 or MLH1. Cancer Cell 2010, 17:235-248.

121. des Guetz G, Schischmanoff O, Nicolas P, Perret GY, Morere JF, Uzzan B: Does microsatellite instability predict the efficacy of adjuvant chemotherapy in colorectal cancer? A systematic review with metaanalysis. Eur J Cancer 2009, 45:1890-1896.

122. Ribic CM, Sargent DJ, Moore MJ, Thibodeau SN, French AJ, Goldberg RM, Hamilton SR, Laurent-Puig P, Gryfe R, Shepherd LE, Tu D, Redston M, Gallinger S: Tumor microsatellite-instability status as a predictor of 
benefit from fluorouracil-based adjuvant chemotherapy for colon cancer. N Engl J Med 2003, 349:247-257.

123. Sargent DJ, Marsoni S, Monges G, Thibodeau SN, Labianca R, Hamilton SR, French AJ, Kabat B, Foster NR, Torri V, Ribic C, Grothey A, Moore M, Zaniboni A, Seitz JF, Sinicrope F, Gallinger S: Defective mismatch repair as a predictive marker for lack of efficacy of fluorouracil-based adjuvant therapy in colon cancer. J Clin Oncol 2010, 28:3219-3226.

124. de Vos tot Nederveen Cappel WH, Meulenbeld HJ, Kleibeuker JH, Nagengast FM, Menko FH, Griffioen G, Cats A, Morreau H, Gelderblom H, Vasen HF: Survival after adjuvant 5-FU treatment for stage III colon cancer in hereditary nonpolyposis colorectal cancer. Int J Cancer 2004 109:468-471.

125. Sinicrope FA, Sargent DJ: Clinical implications of microsatellite instability in sporadic colon cancers. Curr Opin Oncol 2009, 21:369-373.

126. de la Chapelle A, Hampel H: Clinical relevance of microsatellite instability in colorectal cancer. J Clin Oncol 2010, 28:3380-3387.

127. Kim ST, Lee J, Park SH, Park JO, Lim HY, Kang WK, Kim JY, Kim YH, Chang DK, Rhee PL, Kim DS, Yun H, Cho YB, Kim HC, Yun SH, Lee WY, Chun HK, Park YS: Clinical impact of microsatellite instability in colon cancer following adjuvant FOLFOX therapy. Cancer Chemother Pharmacol 2010, 66:659-667.

128. Zaanan A, Cuilliere-Dartigues P, Guilloux A, Parc Y, Louvet C, de Gramont A, Tiret E, Dumont S, Gayet B, Validire P, Fléjou JF, Duval A, Praz F: Impact of p53 expression and microsatellite instability on stage III colon cancer disease-free survival in patients treated by 5 -fluorouracil and leucovorin with or without oxaliplatin. Ann Oncol 2010, 21:772-780.

129. Bertagnolli MM, Niedzwiecki D, Compton CC, Hahn HP, Hall M, Damas B, Jewell SD, Mayer RJ, Goldberg RM, Saltz LB, Warren RS, Redston M: Microsatellite instability predicts improved response to adjuvant therapy with irinotecan, fluorouracil, and leucovorin in stage III colon cancer: Cancer and Leukemia Group B Protocol 89803. J Clin Oncol 2009, 27:1814-1821

130. Liang JT, Huang KC, Lai HS, Lee PH, Cheng YM, Hsu HC, Cheng AL, Hsu CH, Yeh KH, Wang SM, Tang C, Chang KJ: High-frequency microsatellite instability predicts better chemosensitivity to high-dose 5 -fluorouracil plus leucovorin chemotherapy for stage IV sporadic colorectal cancer after palliative bowel resection. Int J Cancer 2002, 101:519-525.

131. Brueckl WM, Moesch C, Brabletz T, Koebnick C, Riedel C, Jung A, Merkel S, Schaber S, Boxberger F, Kirchner T, Hohenberger W, Hahn EG, Wein A: Relationship between microsatellite instability, response and survival in palliative patients with colorectal cancer undergoing first-line chemotherapy. Anticancer Res 2003, 23:1773-1777.

132. des Guetz G, Mariani P, Cucherousset J, Benamoun M, Lagorce C, Sastre X, Le Toumelin P, Uzzan B, Perret GY, Morere JF, Breau JL, Fagard R, Schischmanoff PO: Microsatellite instability and sensitivitiy to FOLFOX treatment in metastatic colorectal cancer. Anticancer Res 2007, 27:2715-2719.

133. Müller Cl, Schulmann K, Reinacher-Schick A, Andre N, Arnold D, Tannapfel A, Arkenau H, Hahn SA, Schmoll SH, Porschen R, Schmiegel W, Graeven U, AlO Colorectal Study Group: Predictive and prognostic value of microsatellite instability in patients with advanced colorectal cancer treated with a fluoropyrimidine and oxaliplatin containing first-line chemotherapy. A report of the AlO Colorectal Study Group. Int J Colorectal Dis 2008, 23:1033-1039.

134. Kim ST, Lee J, Park SH, Park JO, Lim HY, Kang WK, Kim JY, Kim YH, Chang DK, Rhee PL, Kim DS, Yun H, Cho YB, Kim HC, Yun SH, Chun HK, Lee WY, Park YS: The effect of DNA mismatch repair (MMR) status on oxaliplatin-based first-line chemotherapy as in recurrent or metastatic colon cancer. Med Oncol 2010, 27:1277-1285.

135. Fallik D, Borrini F, Boige V, Viguier J, Jacob S, Miquel C, Sabourin JC, Ducreux M, Praz F: Microsatellite instability is a predictive factor of the tumor response to irinotecan in patients with advanced colorectal cancer. Cancer Res 2003, 63:5738-5744.

136. Charara M, Edmonston TB, Burkholder S, Walters R, Anne P, Mitchell E, Fry R, Boman B, Rose D, Fishel R, Curran W, Palazzo J: Microsatellite status and cell cycle associated markers in rectal cancer patients undergoing a combined regimen of 5-FU and CPT-11 chemotherapy and radiotherapy. Anticancer Res 2004, 24:3161-3167.

137. Bendardaf R, Lamlum $H$, Ristamäki R, Korkeila E, Syrjänen $K$, Pyrhönen $S$ : Mismatch repair status is a predictive factor of tumour response to 5- fluorouracil and irinotecan chemotherapy in patients with advanced colorectal cancer. Tumour Biol 2007, 28:212-220.

138. Kim JE, Hong YS, Ryu MH, Lee JL, Chang HM, Lim SB, Kim JH, Jang SJ, Kim MJ, Yu CS, Kang YK, Kim JC, Kim TW: Association between deficient mismatch repair system and efficacy to irinotecan-containing chemotherapy in metastatic colon cancer. Cancer Sci 2011.

139. Burn J, Bishop DT, Mecklin JP, Macrae F, Möslein G, Olschwang S, Bisgaard ML, Ramesar R, Eccles D, Maher ER, Bertario L, Jarvinen HJ, Lindblom A, Evans DG, Lubinski J, Morrison PJ, Ho JW, Vasen HF, Side L, Thomas HJ, Scott RJ, Dunlop M, Barker G, Elliott F, Jass JR, Fodde R, Lynch HT, Mathers JC, CAPP2 Investigators: Effect of aspirin or resistant starch on colorectal neoplasia in the Lynch syndrome. N Engl J Med 2008, 359:2567-2578.

140. Half E, Bercovich D, Rozen P: Familial adenomatous polyposis. Orphanet J Rare Dis 2009, 4:22.

141. Steinbach G, Lynch PM, Phillips RK, Wallace MH, Hawk E, Gordon GB, Wakabayashi N, Saunders B, Shen Y, Fujimura T, Su LK, Levin B: The effect of celecoxib, a cyclooxygenase-2 inhibitor, in familial adenomatous polyposis. N Engl J Med 2000, 342:1946-1952.

142. Bertagnolli MM, Eagle CJ, Zauber AG, Redston M, Breazna A, Kim K, Tang J, Rosenstein RB, Umar A, Bagheri D, Collins NT, Burn J, Chung DC, Dewar T, Foley TR, Hoffman N, Macrae F, Pruitt RE, Saltzman JR, Salzberg B, Sylwestrowicz T, Hawk ET, Adenoma Prevention with Celecoxib Study Investigators: Five-year efficacy and safety analysis of the Adenoma Prevention with Celecoxib Trial. Cancer Prev Res (Phila) 2009, 2:310-321.

143. Vasen HF, Möslein G, Alonso A, Aretz S, Bernstein I, Bertario L, Blanco I, Bülow S, Burn J, Capella G, Colas C, Engel C, Frayling I, Friedl W, Hes FJ, Hodgson S, Järvinen H, Mecklin JP, Møller P, Myrhøi T, Nagengast FM, Parc Y, Phillips R, Clark SK, de Leon MP, Renkonen-Sinisalo L, Sampson JR, Stormorken A, Tejpar S, Thomas HJ, et al: Guidelines for the clinical management of familial adenomatous polyposis (FAP). Gut 2008, 57:704-713.

144. Frank-Raue K, Rondot S, Raue F: Molecular genetics and phenomics of RET mutations: Impact on prognosis of MTC. Mol Cell Endocrinol 2010, $322: 2-7$

145. Carlomagno F, Vitagliano D, Guida T, Ciardiello F, Tortora G, Vecchio G, Ryan AJ, Fontanini G, Fusco A, Santoro M: ZD6474, an orally available inhibitor of KDR tyrosine kinase activity, efficiently blocks oncogenic RET kinases. Cancer Res 2002, 62:7284-7290.

146. Wells SA Jr, Gosnell JE, Gagel RF, Moley J, Pfister D, Sosa JA, Skinner M, Krebs A, Vasselli J, Schlumberger M: Vandetanib for the treatment of patients with locally advanced or metastatic hereditary medullary thyroid cancer. J Clin Oncol 2010, 10:767-772.

147. Robinson BG, Paz-Ares L, Krebs A, Vasselli J, Haddad R: Vandetanib (100 $\mathrm{mg}$ ) in patients with locally advanced or metastatic hereditary medullary thyroid cancer. J Clin Endocrinol Metab 2010, 95:2664-2671.

148. Quinn JE, James CR, Stewart GE, Mulligan JM, White P, Chang GK, Mullan PB, Johnston PG, Wilson RH, Harkin DP: BRCA1 mRNA expression levels predict for overall survival in ovarian cancer after chemotherapy. Clin Cancer Res 2007, 13:7413-7420.

149. Rosell R, Perez-Roca L, Sanchez JJ, Cobo M, Moran T, Chaib I, Provencio M, Domine M, Sala MA, Jimenez U, Diz P, Barneto I, Macias JA, de Las Peñas R, Catot S, Isla D, Sanchez JM, Ibeas R, Lopez-Vivanco G, Oramas J, Mendez P, Reguart N, Blanco R, Taron M: Customized treatment in non-small-cell lung cancer based on EGFR mutations and BRCA1 mRNA expression. PLoS One 2009, 4:e5133.

150. Font A, Taron M, Gago JL, Costa C, Sánchez JJ, Carrato C, Mora M, Celiz P, Perez L, Rodríguez D, Gimenez-Capitan A, Quiroga V, Benlloch S, Ibarz L, Rosell R: BRCA1 mRNA expression and outcome to neoadjuvant cisplatin-based chemotherapy in bladder cancer. Ann Oncol 2011, 22:139-144.

151. Su C, Zhou S, Zhang L, Ren S, Xu J, Zhang J, Lv M, Zhang J, Zhou C: ERCC1, RRM1 and BRCA1 mRNA expression levels and clinical outcome of advanced non-small cell lung cancer. Med Oncol.

152. Papadaki C, Tsaroucha E, Kaklamanis L, Lagoudaki E, Trypaki M, Tryfonidis K, Mavroudis D, Stathopoulos E, Georgoulias V, Souglakos J: Correlation of BRCA1, TXR1 and TSP1 mRNA expression with treatment outcome to docetaxel-based first-line chemotherapy in patients with advanced/ metastatic non-small-cell lung cancer. Br J Cancer 2011, 104:316-323.

153. Holstege $H$, Horlings HM, Velds A, Langerød A, Børresen-Dale AL, van de Vijver MJ, Nederlof PM, Jonkers J: BRCA1-mutated and basal-like breast 
cancers have similar aCGH profiles and a high incidence of protein truncating TP53 mutations. BMC Cancer 2010, 10:654.

154. Vollebergh MA, Lips EH, Nederlof PM, Wessels LF, Schmidt MK, van Beers EH, Cornelissen S, Holtkamp M, Froklage FE, de Vries EG, Schrama JG, Wesseling J, van de Vijver MJ, van Tinteren $\mathrm{H}$, de Bruin M, Hauptmann M, Rodenhuis S, Linn SC: An aCGH classifier derived from BRCA1-mutated breast cancer and benefit of high-dose platinum-based chemotherapy in HER2-negative breast cancer patients. Ann Oncol 2011, 22:1561-1570.

155. Gallmeier E, Kern SE: Absence of specific cell killing of the BRCA2 deficient human cancer cell line CAPAN1 by poly(ADP-ribose) polymerase inhibition. Cancer Biol Ther 2005, 4:703-706.

156. Kloos I, Delaloge $S$, Chompret A, Noguès C, Bressac de Paillerets B, Spielmann M: BRCA1/2-linked breast carcinoma is a highly chemosensitive disease. Proc Am Soc Clin Oncol 2001, 20:abstract 1862.

157. Melichar B, Fridrichová P, Lukesová S, Mergancová J, Urminská H, Ryska A, Foretová L: Pathological complete response after primary chemotherapy in a mother and daughter with hereditary breast carcinoma: two case reports. Eur J Gynaecol Oncol 2008, 29:188-190

158. Rhiem K, Wappenschmidt B, Bosse K, Köppler H, Tutt AN, Schmutzler RK: Platinum sensitivity in a BRCA1 mutation carrier with advanced breast cancer. Clin Oncol (R Coll Radiol) 2009, 21:448-450.

159. Byrski T, Huzarski T, Dent R, Gronwald J, Zuziak D, Cybulski C, Kladny J, Gorski B, Lubinski J, Narod SA: Response to neoadjuvant therapy with cisplatin in BRCA1-positive breast cancer patients. Breast Cancer Res Treat 2009, 115:359-363.

160. Byrski T, Gronwald J, Huzarski T, Grzybowska E, Budryk M, Stawicka M, Mierzwa T, Szwiec M, Wi-niowski R, Siolek M, Narod SA, Lubinski J, Polish Hereditary Breast Cancer Consortium: Response to neo-adjuvant chemotherapy in women with BRCA1-positive breast cancers. Breast Cancer Res Treat 2008, 108:289-296.

161. Leunen K, Cadron I, Van Gorp T, Amant F, Berteloot P, Neven P, Legius E, Vergote I: Does paclitaxel-carboplatin chemotherapy in a dose-dense regimen enhance survival of BRCA-related ovarian cancer patients? Int J Gynecol Cancer 2009, 19:1501-154.

doi:10.1186/1897-4287-9-5

Cite this article as: Imyanitov and Moiseyenko: Drug therapy for hereditary cancers. Hereditary Cancer in Clinical Practice 2011 9:5.

\section{Submit your next manuscript to BioMed Central and take full advantage of:}

- Convenient online submission

- Thorough peer review

- No space constraints or color figure charges

- Immediate publication on acceptance

- Inclusion in PubMed, CAS, Scopus and Google Scholar

- Research which is freely available for redistribution

Submit your manuscript at www.biomedcentral.com/submit 